\title{
A Practitioner's Guide to Intergovernmental Fiscal Transfers
}

\author{
Anwar Shah
}

Revista de Economía y Estadística, Cuarta Época, Vol. 44, No. 2 (2006), pp. 127-186.

http://revistas.unc.edu.ar/index.php/REyE/article/view/4088

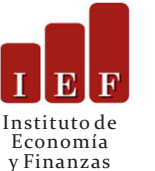

La Revista de Economía y Estadística, se edita desde el año 1939. Es una publicación semestral del Instituto de Economía y Finanzas (IEF), Facultad de Ciencias Económicas, Universidad Nacional de Córdoba, Av. Valparaíso s/n, Ciudad Universitaria. X5000HRV, Córdoba, Argentina.

Teléfono: 00 - 54 - 351 - 4437300 interno 253.

Contacto: rev eco estad@eco.unc.edu.ar

y Finanzas

Dirección web http://revistas.unc.edu.ar/index.php/REyE/index

Cómo citar este documento:

Shah, A. (2006). A Practitioner's Guide to Intergovernmental Fiscal Transfers. Revista de Economía y Estadística, Cuarta Época, Vol. 44, No. 2, pp. 127-186.

Disponible en: <http://revistas.unc.edu.ar/index.php/REyE/article/view/4088>

El Portal de Revistas de la Universidad Nacional de Córdoba es un espacio destinado a la difusión de las investigaciones realizadas por los miembros de la Universidad y a los contenidos académicos y culturales desarrollados en las revistas electrónicas de la Universidad Nacional de Córdoba. Considerando que la Ciencia es un recurso público, es que la Universidad ofrece a toda la comunidad, el acceso libre de su producción científica, académica y cultural.

http://revistas.unc.edu.ar/index.php/index

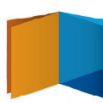




\section{Observatorio de Política}

Esta sección incluye artículos que discuten en forma rigurosa, pero no técnica, temas corrientes de política económica que son de interés por su vinculación al mundo real, aún cuando la literatura económica no los haya todavía incorporado definitivamente y artículos que presentan contenidos teóricos o resultados empíricos con implicancias de política relevantes. Como en todas las revistas en las que esta sección se incluye, un objetivo a destacar es que la misma permite acercar a los investigadores académicos con los formuladores de política aportando, respectivamente unos y otros, desarrollos teórico-conceptuales y empíricos importantes y claridad e información sobre las prioridades de política. Los artículos enviados a para esta Sección están sujetos a los procedimientos normales de referato de la Revista. 



\title{
A Practitioner's Guide to Intergovernmental Fiscal Transfers ${ }^{1}$
}

\author{
ANWAR SHAH* \\ World Bank Institute \\ ashah@worldbank.org
}

The practice of intergovernmental fiscal tranfers is the magical art of passing money from one government to another and seeing it vanish in thin air.

Anonymous

\begin{abstract}
Intergovernmental fiscal transfers are a dominant feature of sub-national finance in most countries. They are used to ensure that revenues roughly match the expenditure needs of various orders (levels) of sub-national governments. They are also used to advance national, regional and local area objectives such as fairness and equity and creating a common economic union. The structure of these transfers create incentives for national, regional and local governments that have a bearing on fiscal management, macroeconomic stability, distributional equity, allocative efficiency and public services delivery. This paper reviews conceptual, empirical and the practice literature to distill lessons of policy interest in designing the fiscal transfers to create the right incentives for prudent fiscal managment and competitive and innovative service delivery. The paper provides practical guidance on the design of performance-oriented

* Dr. Anwar Shah Lead Economist and Program Leader, Public Sector Governance, World Bank Institute, Washington DC.

${ }^{1}$ Forthcoming as a chapter in Boadway and Shah, editors (2007).
\end{abstract}


transfers that emphasize bottom-up, client- focused and results-based government accountability. It cites examples of simple but innovative grant designs that can satisfy grantors' objectives while preserving local autonomy and creating an enabling environment for responsive, responsible, equitable and accountable public governance. The paper further provides guidance on the design and the practice of equalization transfers for regional fiscal equity as well as the institutional arrangements for implementation of such transfer mechanisms.

The paper concludes with negative (practices to avoid) and positive (practices to emulate) lessons from international practices.

Intergovernmental fiscal transfers finance about 60 percent of subnational expenditures in developing countries and transition economies and about a third of such expenditures in OECD countries (29 percent in the Nordic countries, 46 percent in non-Nordic Europe). Beyond the expenditures they finance, these transfers create incentives and accountability mechanisms that affect the fiscal management, efficiency, and equity of public service provision and government accountability to citizens.

This chapter reviews the principles and practices of intergovernmental finance, with a view to drawing some general lessons of relevance to policymakers and practitioners in developing countries and transition economies. It provides a taxonomy of grants, their possible impacts on local fiscal behavior, and the accountability of grant recipients to donor governments and citizens. The first section describes the instruments of intergovernmental finance. Section 2 discusses performance-oriented, or output-based, transfers, an important tool for results-based accountability. Section 3 describes the objectives and design of fiscal transfers in various countries around the world. It shows that in developing countries and transition economies, fiscal transfers focus largely on revenue-sharing transfers, with little attention paid to serving national objectives. It cites examples of simple but innovative grant designs that can satisfy grantors' objectives while preserving local autonomy and creating an enabling environment for responsive, responsible, equitable and accountable public governance. Section 4 describes institutional arrangements for determining these transfers. The last section highlights some lessons of relevance to current policy debates in developing countries and transition economies. It lists practices to avoid as well as those to emulate in designing and implementing grant programs. 


\section{INSTRUMENTS OF INTERGOVERNMENTAL FINANCE}

Intergovernmental transfers or grants can be broadly classified into two categories: general-purpose (unconditional) and specific-purpose (conditional or earmarked) transfers.

\section{General-Purpose Transfers}

General-purpose transfers are provided as general budget support, with no strings attached. These transfers are typically mandated by law, but occasionally they may be of an ad hoc or discretionary nature. Such transfers are intended to preserve local autonomy and enhance interjurisdictional equity. That is why article 9 of the European Charter of Local Self Government advocates such transfers by stating: "As far as possible, grants to local authorities shall not be earmarked for the financing of specific projects. The provision of grants shall not remove the basic freedom of local authorities to exercise policy discretion within their own jurisdiction." (Barati and Szalai 2000, p.21)

General-purpose transfers are termed bloc transfers when they are used to provide broad support in a general area of subnational expenditures (such as education) while allowing recipients discretion in allocating the funds among specific uses. Bloc grants are a vaguely defined concept. They fall in the grey area between general-purpose and specific-purpose transfers, as they provide budget support with no strings attached in a broad but specific area of subnational expenditures.

General-purpose transfers simply augment the recipient's resources. They have only an income effect as indicated in Figure 1.1 by the shift in the recipient's budget line $\mathrm{AB}$ upwards and to the right throughout by the amount of the grant $(\mathrm{AC}=\mathrm{BD})$ and the new budget line becomes $\mathrm{CD}$. Since the grant can be spent on any combination of public goods or services or used to provide tax relief to residents, general nonmatching assistance does not affect relative prices (no substitution effect). It is also the least stimulative of local spending, typically increasing such spending by less than $\$ 0.50$ for each additional $\$ 1$ of unconditional assistance. The remaining funds are made available as tax relief to local residents to spend on private goods and services . 
Figure 1.1

Effect of Unconditional Nonmatching Grant

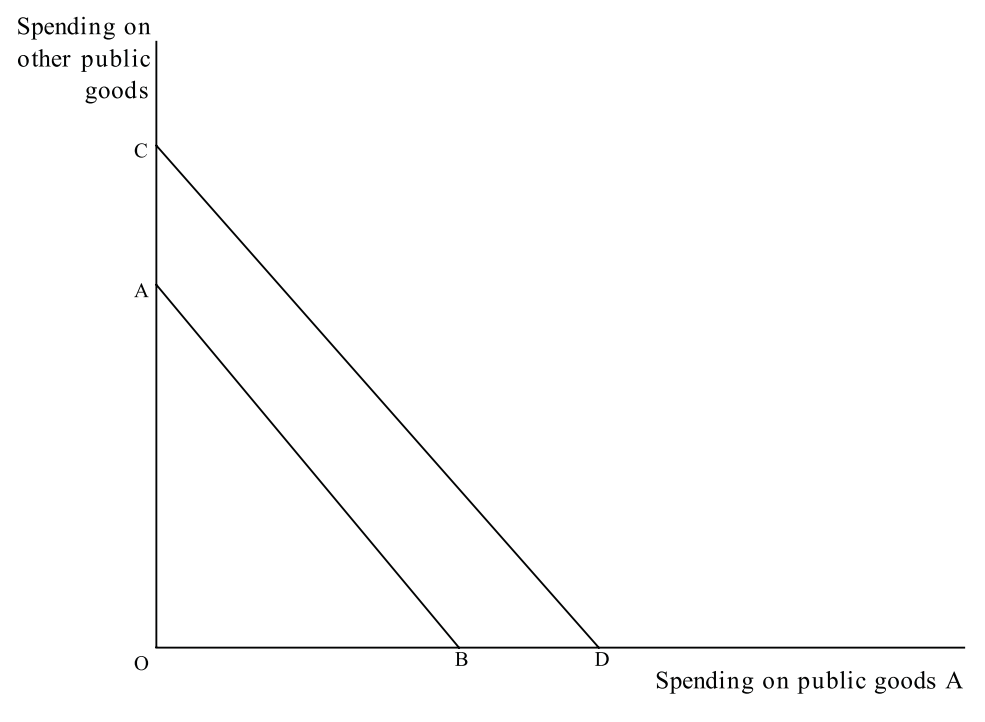

Source: Shah (1994)

Conceptually a one dollar increase in local residents' income should have exactly the same impact on local public spending as receipt of one dollar of general purpose transfer. Both tend to shift the budget line outwards identically. Contrary to this, all empirical studies show that a dollar received by the community in the form of general purpose grant tends to have a greater increase in local public spending more than a dollar increase in residents' income i.e. the portion of grants retained for local spending tends to exceed the effective tax rate imposed by local governments on resident's incomes (Rosen 2005, Oates 1999, Gramlich 1977; chapter 8 of this volume). Grant money tends to stick where it first lands, leaving a smaller than expected fraction available for tax relief, a phenomenon referred to as the "flypaper effect." The implication is that for political and bureaucratic reasons, grants to local governments tend to result in more local spending than they would have had the same transfers been made directly to local residents (McMillan, Shah, and Gillen 1980). An explanation for this impact is provided by the hypothesis that bureaucrats seeks to maximize the size of their budgets as it gives them greater power and influence in local community (Filimon, Romer and Rosenthal 1982). 
Formula-based general-purpose transfers are very common. The federal and state transfers to municipalities in Brazil are examples of grants of this kind. Evidence suggests that such transfers induce municipalities to underutilize their own tax bases (Shah, 1991).

\section{Specific-Purpose Transfers}

Specific-purpose, or conditional, transfers are intended to provide incentives for governments to undertake specific programs or activities. These grants may be regular or mandatory in nature or discretionary or ad hoc.

Conditional transfers typically specify the type of expenditures that can be financed (input-based conditionality). These may be capital expenditures, operating expenditures, or both. Conditional transfers may also require attainment of certain results in service delivery (output-based conditionality). Input-based conditionality is often intrusive and unproductive, whereas output-based conditionality can advance grantors' objectives while preserving local autonomy.

Conditional transfers may incorporate matching provisions requiring grant recipients to finance a specified percentage of expenditures using their own resources. Matching requirements can be either open ended, meaning that the grantor matches whatever level of resources the recipient provides, or closed ended, meaning that the grantor matches recipient funds only up to a pre-specified limit.

Matching requirements encourage greater scrutiny and local ownership of grant-financed expenditures; closed-ended matching is helpful in ensuring that the grantor has some control over the costs of the transfer program. Matching requirements, however, represent a greater burden for a recipient jurisdiction with limited fiscal capacity. . In view of this, it may be desirable to set matching rates in inverse proportion to the per capita fiscal capacity of the jurisdiction in order to allow poorer jurisdictions to participate in grant-financed programs.

\section{Nonmatching Transfers}

Conditional nonmatching transfers provide a given level of funds without local matching, as long the funds are spent for a particular purpose. Following the grant $(=\mathrm{AC})$, the budget line in Figure 1.2 shifts 
from $\mathrm{AB}$ to $\mathrm{ACD}$, where at least $\mathrm{OE}(=\mathrm{AC})$ of the assisted public good will be acquired.

Figure 1.2

Effect of Conditional Nonmatching Grant

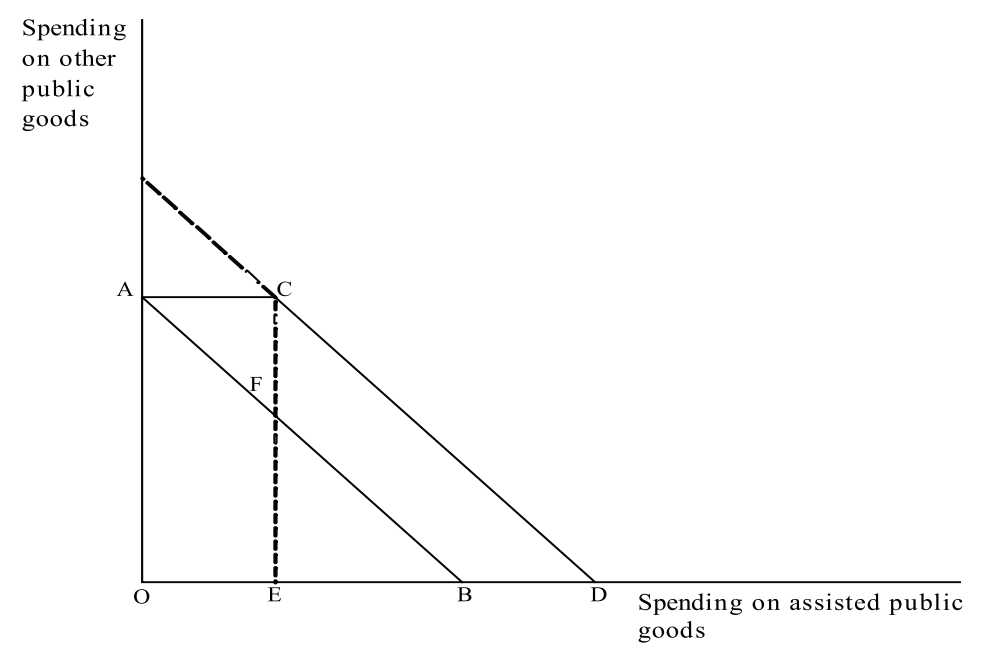

Source: Shah (1994)

Conditional nonmatching grants are best suited for subsidizing activities considered high priority by a higher-level government but low priority by local governments. This may be the case if a program generates a high degree of spillovers up to a given level of provision (OE), after which the external benefits terminate abruptly.

For a given level of available assistance, grant recipients prefer unconditional nonmatching transfers, which provide them with maximum flexibility to pursue their own objectives. Because such grants augment resources without influencing spending patterns, they allow recipients to maximize their own welfare. Grantors, however, may be prepared to sacrifice some recipient satisfaction to ensure that the funds are directed toward expenditures on which they place a priority. This is particularly so when federal objectives are implemented by line agencies or departments rather than through a central agency, such as the Ministry of Finance, with a broader mandate. Federal departments do not want local governments to 
shift their program funds toward other areas. In this situation, conditional (selective) nonmatching (bloc) grants can ensure that the funds are spent in a department's area of interest (for example, health care) without distorting local priorities among alternative activities or inducing inefficient allocations in the targeted expenditure area.

\section{Matching Transfers}

Conditional matching grants, or cost-sharing programs, require that funds be spent for specific purposes and that the recipient match the funds to some degree. Figure 1.3 shows the effect on a local government budget of a 25 percent subsidy program for transportation. AB indicates the no subsidy line - the combination of transportation and other public goods and services a city can acquire with a budget of $\mathrm{OA}=\mathrm{OB}$. A federal subsidy of 25 percent of transportation expenditures (that is, a grant of $\$ 1$ for every $\$ 3$ of local funds for spent on transportation) shifts the budget line of attainable combinations to AC. At any level of other goods and services, the community can obtain one-third more transportation services. If the community chooses combination $\mathrm{M}$ before the grant, it will likely select a combination such as $\mathrm{N}$ afterward. At $\mathrm{N}$ more transportation is acquired.

Figure 1.3

\section{Effect of Open-Ended Matching Grant}

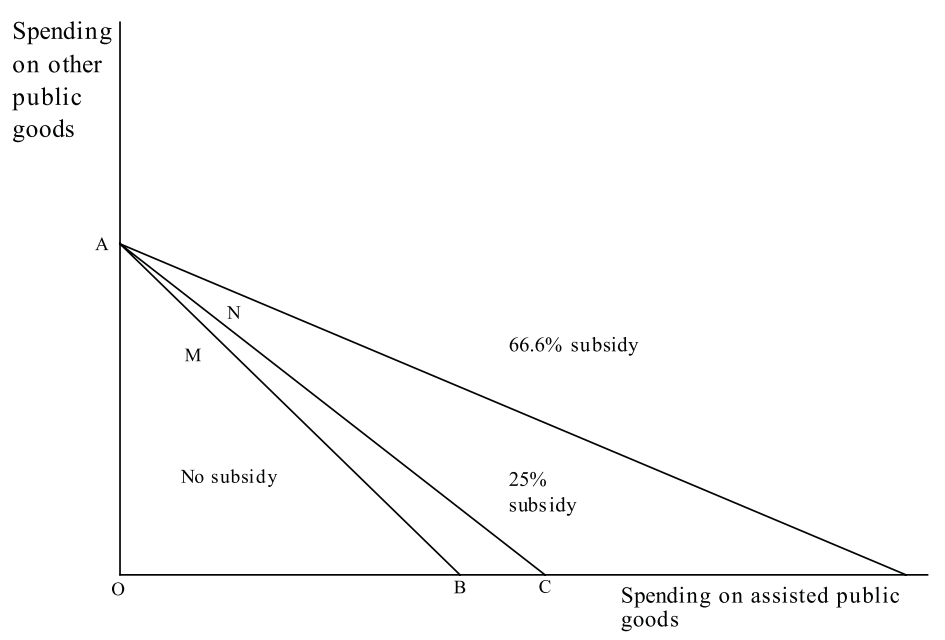

Source: Shah (1994) and McMillan, Shah and Gillen (1980) 
The subsidy has two effects, an income effect and a substitution effect. The subsidy gives the community more resources, some of which go to acquiring more transportation services (the income effect). Since the subsidy reduces the relative price of transportation services, the community acquires more transportation services from a given budget (the substitution effect). Both effects stimulate higher spending on transportation.

Although the grant is for transportation, more other public goods and services may also be acquired, even though they become relatively more expensive, as a result of the substitution effect. If the income effect is sufficiently large, it will dominate and the grant will increase consumption of other goods and services. Most studies find that for grants of this kind, spending in the specified area increases by less than the amount of the grant, with the remainder going toward other public goods and services and tax relief. This is the so-called fungibility effect of grants. The fungibility of conditional grants depends on both the level of spending on the assisted public service and the relative priority of such spending. For example, if the recipient's own-financed expenditure on the assisted category exceeds the amount of the conditional grant, the conditionality of the grant may or may not have any impact on the recipient's spending behavior: all, some, or none of the grant funds could go to the assisted function. Shah $(1985,1988 b, 1989)$ finds that while provincial assistance to cities in Alberta for public transit was partially diverted to finance other services, similar assistance for road transportation improvement was not.

Open-ended matching grants, in which no limit is placed on available assistance through matching provisions, are well suited for correcting inefficiencies in the provision of public goods arising from benefit spillovers, or externalities. Benefit spillovers occur when services provided and financed by a local government also benefit members of other local governments that do not contribute to their provision. Because the providing government bears all the costs but obtains only a portion of the benefits, it tends to underprovide the goods. If the affected communities cannot negotiate compensation, the situation can be corrected by a higher government subsidizing provision of the service, with the extent of the spillover determining the degree of subsidy or the matching ratio.

Matching grants can correct inefficiencies from spillovers, but they do not address uneven or inadequate fiscal capacities across state and local governments. Local governments with ample resources can afford to meet matching requirements and acquire a substantial amount of assistance. States with limited fiscal capacities may be unable to match federal funds 
and therefore fail to obtain as much assistance, even though their expenditure needs may be equal to or greater than those of wealthier states (Shah 1991). Other forms of assistance are needed to equalize fiscal capacities in such cases.

Grantors usually prefer closed-ended matching transfers, in which funds are provided to a certain limit, since such transfers permit them to retain control over their budgets. Figure 1.4 shows the effect of closedended matching grants on the local budget. $\mathrm{AB}$ is the original budget line. When $\$ 1$ of assistance is available for every $\$ 3$ of local funds spent up to a prespecified limit, the budget line becomes ACD. Initially, costs are shared on a one-third:two-thirds basis up to a level of OF, at which the subsidy limit of $\mathrm{CG}(=\mathrm{CE})$ is reached. Expenditures beyond OF receive no subsidy, so the slope of the budget line reverts back to 1:1 rather than 1:3 along the subsidized segment, AC.

Empirical studies typically find that closed-ended grants stimulate expenditures on the subsidized activity more than open-ended grants (Gramlich 1977; Shah 1994b; Gamkhar and Shah, 2006). The estimated response to an additional $\$ 1.00$ of this kind of grant is typically $\$ 1.50$. Institutional factors may explain this surprisingly large response.

Figure 1.4

Effect of Closed-Ended Matching Grant

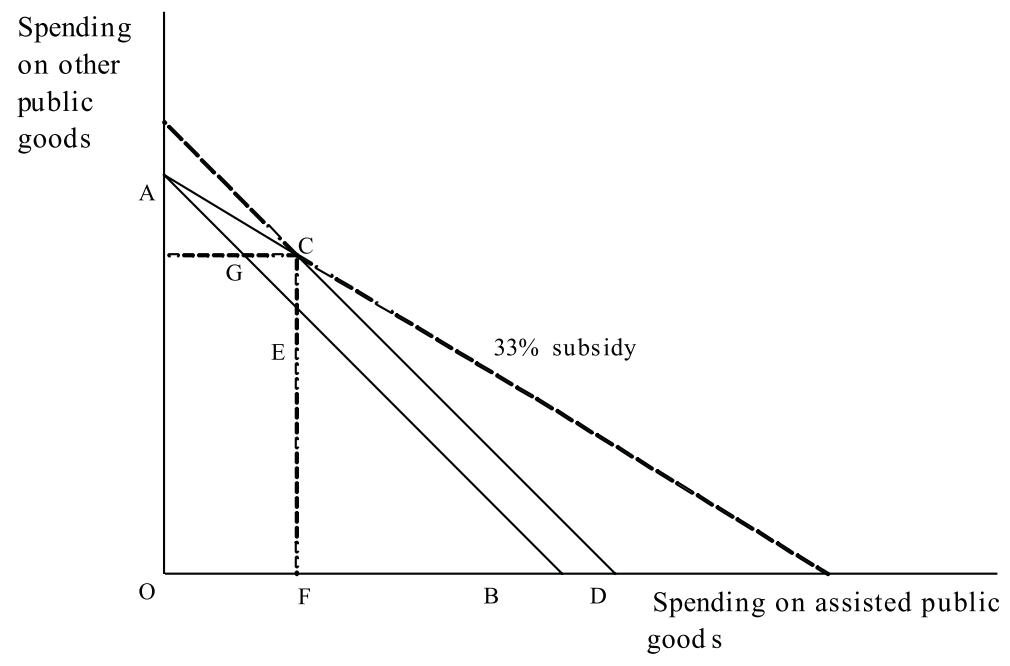

Source: Shah (1994) 
Why are conditional closed-ended matching grants common in industrial countries when they seem ill designed to solve problems and inefficiencies in the provision of public goods? The answer seems to be that correcting for inefficiencies is not the sole or perhaps even the primary objective. Instead, grants are employed to help local governments financially while promoting spending on activities given priority by the grantor. The conditional (selective) aspects of or conditions on the spending are expected to ensure that the funds are directed toward an activity the grantor views as desirable. This, however, may be false comfort in view of the potential for fungibility of funds. The local matching or cost-sharing component affords the grantor a degree of control, requires a degree of financial accountability by the recipient, and makes the cost known to the granting government.

Conditional closed-ended matching grants have advantages and disadvantages from the grantor's perspective. While such grants may result in a significant transfer of resources, they may distort output and cause inefficiencies, since the aid is often available only for a few activities, causing overspending on these functions while other functions are underfinanced. If capital outlays are subsidized while operating costs are not, grants may induce spending on capital-intensive alternatives.

Conditional open-ended matching grants are the most suitable vehicles to induce lower-level governments to increase spending on the assisted function (table 1.1). If the objective is simply to enhance the welfare of local residents, general-purpose nonmatching transfers are preferable, as they preserve local autonomy.

To ensure accountability for results, conditional nonmatching output-based transfers are preferable to other types of transfers. Outputbased transfers respect local autonomy and budgetary flexibility while providing incentives and accountability mechanisms to improve service delivery performance. The design of such transfers is discussed in the next section. 


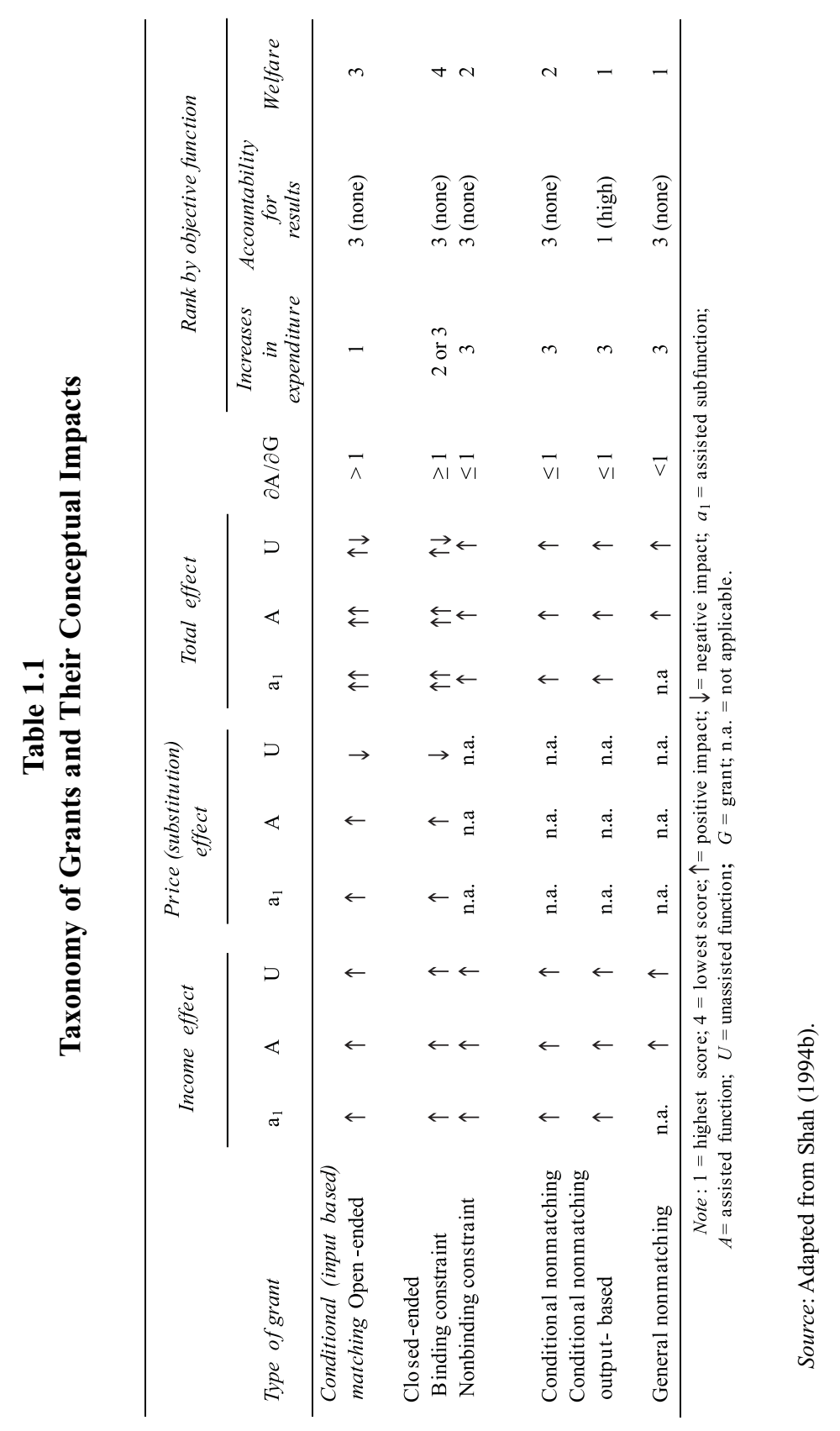




\section{Achieving Results-Based Accountability through Performance-Oriented Transfers}

Economic rationales for output-based grants (used interchangeably with performance-oriented transfers in this chapter) stem from the emphasis on contract-based management under the new public management framework and strengthening demand for good governance by lowering the transactions costs for citizens in obtaining public services under the new institutional economics approach. The new public management framework seeks to strengthen accountability for results by changing the management paradigm in the public sector from permanent appointments to contractual appointment and continuation of employment subject to fulfillment of service delivery contracts. It seeks to create a competitive service delivery environment by making financing available on similar conditions to all providers -government and non-government.

The new institutional economics approach argues that dysfunctional governance in the public sector results from opportunistic behavior by public officials, as citizens are either not empowered to hold public officials accountable for their noncompliance with their mandates and/or for corrupt acts or face high transactions costs in doing so. In this framework, citizens are treated as the principals and public officials the agents. The principals have bounded rationality - they act rationally based on the incomplete information they have. Acquiring and processing information about public sector operations is costly. Agents (public officials) are better informed than principals. Their self-interest motivates them to withhold information from the public domain, as releasing such information helps principals hold them accountable. This asymmetry of information allows agents to indulge in opportunistic behavior which goes unchecked due to high transactions costs faced by the principals and a lack of or inadequacy of countervailing institutions to enforce accountable governance. Results-based accountability through output-based grants empowers citizens by increasing their information base and lowering their transactions costs in demanding action.

Output-based transfers link grant finance with service delivery performance. These transfers place conditions on the results to be achieved while providing full flexibility in the design of programs and associated spending levels to achieve those objectives. Such transfers help restore recipients' focus on the results-based chain (figure 1.5) and the alternate service delivery framework (competitive framework for public service delivery) to achieve those results. In order to achieve grant objectives, a 
public manager in the recipient government would examine the resultsbased chain to determine whether or not program activities are expected to yield the desired results. To do so, he or she needs to monitor program activities and inputs, including intermediate inputs (resources used to produce outputs), outputs (quantity and quality of public goods and services produced and access to such goods and services), outcomes (intermediateto long-run consequences for consumers/taxpayers of public service provision or progress in achieving program objectives), impact (program goals or very long-term consequences of public service provision), and reach (people who benefit from or are hurt by a program). Such a managerial focus reinforces joint ownership and accountability of the principal and the agent in achieving shared goals by highlighting terms of mutual trust. Thus internal and external reporting shifts from the traditional focus on inputs to a focus on outputs, reach, and outcomes - in particular, outputs that lead to results. Flexibility in project definition and implementation is achieved by shifting emphasis from strict monitoring of inputs to monitoring performance results and their measurements. Tracking progress toward expected results is done through indicators, which are negotiated between the provider and the financing agency. This joint goal setting and reporting helps ensure client satisfaction on an ongoing basis while building partnership and ownership into projects (Shah 2005b).

Figure 1.5

Applying a Results - Based Chain to Education

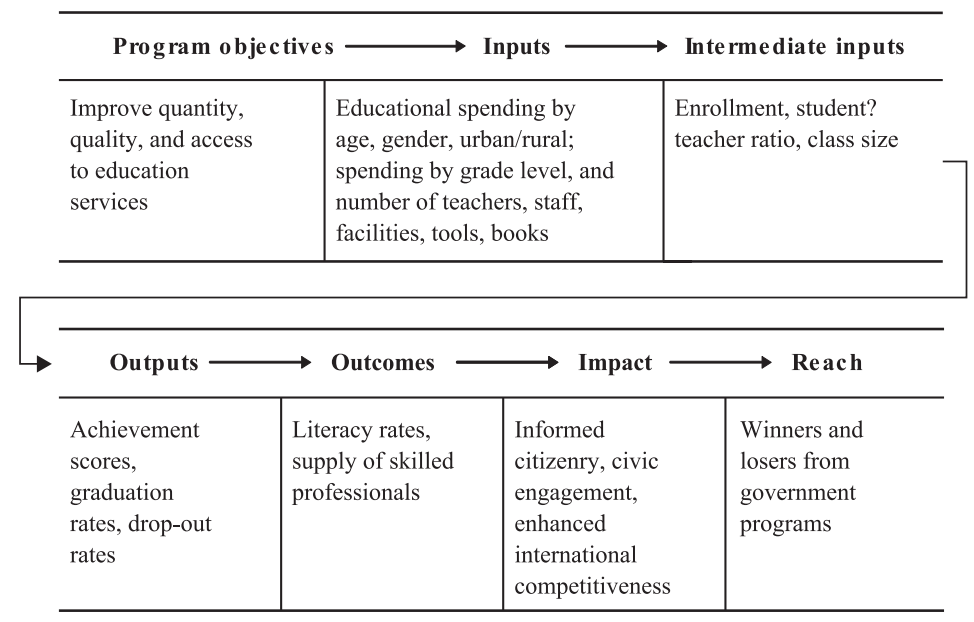


Output-based grants must have conditions on outputs as opposed to outcomes, as outcomes are subject to influence by factors beyond the control of a public manager. Public managers should be held accountable only for factors under their control. Outcome-based conditions diffuse enforcement of accountability for results. Since the grant conditions are concerned with service delivery performance in terms of quality of output and access, the manager is free to choose the program and inputs to deliver results. To achieve those results, he or she faces positive incentives by grant conditions that encourage alternate service delivery mechanisms by contracting out, outsourcing, or simply encouraging competition among government and nongovernment providers. This can be done by establishing a level playing field through at par financing, by offering franchises through competitive bidding, or by providing rewards for performance through benchmarking or yardstick competition. Such an incentive environment is expected to yield a management paradigm that emphasizes results-based accountability to clients with the following common elements:

- Contracts or work program agreements based on pre-specified outputs and performance targets and budgetary allocations.

- Replacement of lifelong rotating employment with contractual appointments with task specialization.

- Managerial flexibility but accountability for results.

- Redefinition of public sector role as purchaser but not necessarily provider of public services.

- Adoption of the subsidiarity principle - that is, public sector decisions made at the level of government closest to the people, unless a convincing case can be made not to do so.

- Incentives for cost efficiency.

- Incentives for transparency and competitive service provision.

- Accountability to taxpayers.

Under such an accountable governance framework, grant-financed budget allocations support contracts and work program agreements, which are based on prespecified outputs and performance targets. The grant recipient's flexibility in input selection -including hiring and firing of personnel and implementation of programs - is fully respected, but there is strict accountability for achieving results. The incentive and accountability 
regime created by output-based transfers is expected to create responsive, responsible, and accountable governance without undermining local autonomy. In contrast, traditional conditional grants with input conditionality undermine local autonomy and budgetary flexibility while reinforcing a culture of opportunism and rent seeking (Table 1.2).

Table 1.2

Features of Traditional and Output-Based Conditional Grants

\begin{tabular}{|c|c|c|}
\hline Feature & Traditional grant & Output-based grant \\
\hline Grant objectives & Spending levels & $\begin{array}{l}\text { Quality and access to public } \\
\text { services }\end{array}$ \\
\hline $\begin{array}{l}\text { Grant design and } \\
\text { administration }\end{array}$ & Complex & Simple and transparent \\
\hline Eligibility & $\begin{array}{l}\text { Recipient government } \\
\text { departments/agencie }\end{array}$ & $\begin{array}{l}\text { Recipient government } \\
\text { provides funds to all } \\
\text { government and } \\
\text { nongovernment providers }\end{array}$ \\
\hline Conditions & $\begin{array}{l}\text { Expenditures on authorized } \\
\text { functions and objects }\end{array}$ & $\begin{array}{l}\text { Outputs-service delivery } \\
\text { results }\end{array}$ \\
\hline Allocation criteria & $\begin{array}{l}\text { Program or project } \\
\text { proposals approvals } \\
\text { with expenditure details }\end{array}$ & $\begin{array}{l}\text { Demographic data on } \\
\text { potential clients }\end{array}$ \\
\hline $\begin{array}{l}\text { Compliance } \\
\text { verification }\end{array}$ & $\begin{array}{l}\text { Higher level inspections and } \\
\text { audits }\end{array}$ & $\begin{array}{l}\text { Client feedback and redress, } \\
\text { comparison of baseline and } \\
\text { postgrant data on quality } \\
\text { and access }\end{array}$ \\
\hline Penalties & $\begin{array}{l}\text { Audit observations on } \\
\text { financial compliance }\end{array}$ & $\begin{array}{l}\text { Public censure, competitive } \\
\text { pressures, voice and exit } \\
\text { options for clients }\end{array}$ \\
\hline Managerial flexibility & $\begin{array}{l}\text { Little or none. No tolerance } \\
\text { for risk and no } \\
\text { accountability for failure }\end{array}$ & $\begin{array}{l}\text { Absolute. Rewards for risks } \\
\text { but penalties for persistent } \\
\text { failure }\end{array}$ \\
\hline $\begin{array}{l}\text { Local government } \\
\text { autonomy and } \\
\text { budgetary flexibility }\end{array}$ & Little & Absolute \\
\hline Transparency & Little & Absolute \\
\hline Focus & Internal & $\begin{array}{l}\text { External, competition, } \\
\text { innovation and } \\
\text { benchmarking }\end{array}$ \\
\hline Accountability & $\begin{array}{l}\text { Hierarchical to higher-level } \\
\text { government, controls on } \\
\text { inputs and process with little } \\
\text { or no concern for results }\end{array}$ & $\begin{array}{l}\text { Results-based, bottom-up, } \\
\text { client-driven }\end{array}$ \\
\hline
\end{tabular}

Source: Author. 
Output-based grants create incentive regimes that promote a resultsbased accountability culture. Consider the case in which the national government aims to improve access to education by the poor and to enhance the quality of such education. A common approach is to provide grants to government schools through conditional grants. These grants specify the type of expenditures eligible for grant financing (books, computers, teacher aids, and so forth) as well as financial reporting and audit requirements. Such input conditionality undermines budgetary autonomy and flexibility without providing any assurance about the achievement of results. Moreover, in practice it is difficult to enforce, as there may be significant opportunities for fungibility of funds. Experience has shown that there is no one-to-one link between increases in public spending and improvements in service delivery performance (see Huther, Roberts, and Shah 1997).

Output-based design of such grants can help achieve accountability for results. Under this approach, the national government allocates funds to local governments based on the size of the school-age population. Local governments in turn pass these funds on to both government and nongovernment providers based on school enrollments. Non-government providers are eligible to receive grant funds if they admit students based on merit and provide a tuition subsidy to students whose parents cannot afford the tuition. All providers are expected to improve or at the minimum maintain baseline achievement scores on standardized tests, increase graduation rates, and reduce dropout rates. Failure to do so will invite public censure and in the extreme case cause grant funds to be discontinued. In the meantime, reputation risks associated with poor performance may reduce enrollments, thereby reducing the grant funds received. Schools have full autonomy in the use of grant funds and are able to retain unused funds.

This kind of grant financing would create an incentive environment for both government and non-government schools to compete and excel to retain students and establish reputations for quality education, as parental choice determines grant financing to each school. Such an environment is particularly important for government schools, where staff have lifelong appointments and financing is ensured regardless of performance. Budgetary flexibility and retention of savings would encourage innovation to deliver quality education. 
Output-based grants thus preserve autonomy, encourage competition and innovation, and bring strict accountability for results to residents. This accountability regime is self-enforcing through consumer (parental choice in the current example) choice.

\section{Designing Fiscal Transfers: Dividing the Spoils or Creating a Framework for Accountable and Equitable GOVERNANCE?}

The design of fiscal transfers is critical to ensuring the efficiency and equity of local service provision and the fiscal health of subnational governments (for a comprehensive treatment of the economic rationale of intergovernmental fiscal transfers, see Boadway and Shah forthcoming). A few simple considerations can be helpful in designing these transfers:

\section{Guidelines for Grant Design}

1) Clarity in grant objectives. Grant objectives should be clearly and precisely specified to guide grant design.

2) Autonomy. Subnational governments should have complete independence and flexibility in setting priorities. They should not be constrained by the categorical structure of programs and uncertainty associated with decisionmaking at the center. Tax-base sharing - allowing subnational governments to introduce their own tax rates on central bases, formula-based revenue sharing, or bloc grants - is consistent with this objective.

3) Revenue adequacy. Subnational governments should have adequate revenues to discharge designated responsibilities.

4) Responsiveness. The grant program should be flexible enough to accommodate unforeseen changes in the fiscal situation of the recipients.

5) Equity (fairness). Allocated funds should vary directly with fiscal need factors and inversely with the tax capacity of each jurisdiction.

6) Predictability. The grant mechanism should ensure predictability of subnational governments' shares by publishing five-year projections of funding availability. The grant formula should 
specify ceilings and floors for yearly fluctuations. Any major changes in the formula should be accompanied by hold harmless or grandfathering provisions.

7) Transparency. Both the formula and the allocations should be disseminated widely, in order to achieve as broad a consensus as possible on the objectives and operation of the program.

8) Efficiency. The grant design should be neutral with respect to subnational governments' choices of resource allocation to different sectors or types of activity.

9) Simplicity. Grant allocation should be based on objective factors over which individual units have little control. The formula should be easy to understand, in order not to reward grantsmanship.

10) Incentive. The design should provide incentives for sound fiscal management and discourage inefficient practices. Specific transfers to finance subnational government deficits should not be made.

11) Reach. All grant-financed programs create winners and losers. Consideration must be given to identifying beneficiaries and those who will be adversely affected to determine the overall usefulness and sustainability of the program.

12) Safeguarding of grantor's objectives. Grantor's objectives are best safeguarded by having grant conditions specify the results to be achieved (output-based grants) and by giving the recipient flexibility in the use of funds.

13) Affordability. The grant program must recognize donors' budget constraints. This suggests that matching programs should be closed ended.

14) Singular focus. Each grant program should focus on a single objective.

15) Accountability for results. The grantor must be accountable for the design and operation of the program. The recipient must be accountable to the grantor and its citizens for financial integrity and results - that is, improvements in service delivery performance. Citizens' voice and exit options in grant design can help advance bottom-up accountability objectives.

Some of these criteria may be in conflict with others. Grantors may 
therefore have to assign priorities to various factors in comparing design alternatives (Shah 1994b); Canada 2006).

For enhancing government accountability to voters, it is desirable to match revenue means (the ability to raise revenues from own sources) as closely as possible with expenditure needs at all levels of government. However, higher-level governments must be allowed greater access to revenues than needed to fulfill their own direct service responsibilities, so that they are able to use their spending power through fiscal transfers to fulfill national and regional efficiency and equity objectives.

Six broad objectives for national fiscal transfers can be identified. Each of these objectives may apply to varying degrees in different countries; each calls for a specific design of fiscal transfers. Lack of attention in design to specific objectives leads to negative perceptions of these grants (Box 1.1).

\section{Box 1.1 Well-Founded Negative Perceptions of Intergovernmental Finance}

Perceptions of intergovernmental finance are generally negative. Many federal officials believe that giving money and power to subnational governments is like giving whiskey and car keys to teenagers. They believe that grant monies enable these governments to go on spending binge and the national government then is faced with the consequences of their reckless spending behaviors. Past spending behavior of provincial and local officials also demonstrates that 'grant money does not buy anything' meaning that it is treated as a windfall gain and wastefully expended with little to show for in service delivery improvements. Citizens perceive the granting of intergovernmental fiscal transfers as the magical art of passing money from one government to another and seeing it vanish into thin air.

These perceptions are well grounded in reality in developing countries, where the primary focus of fiscal transfers is on dividing the spoils. In developing (and industrial) countries, four types of transfers are common:

- Passing the buck transfers. These are general revenue-sharing programs that employ multiple factors that work at cross purposes. Argentina, Brazil, India, the Philippines, and many other countries have such ongoing programs. 
- Asking for more trouble grants. These are grants that finance subnational deficits, in the process encouraging higher and higher deficits. China, Hungary, and India provide this type of grants.

- Pork barrel transfers. In the past politically opportunistic grants were common in Brazil and Pakistan. They are currently in vogue in India and Western countries especially the United States of America.

- Command and control transfers. These are grants with conditions on inputs. They are used to micromanage and interfere in local decisionmaking. They are widely practiced in most industrial and developing countries.

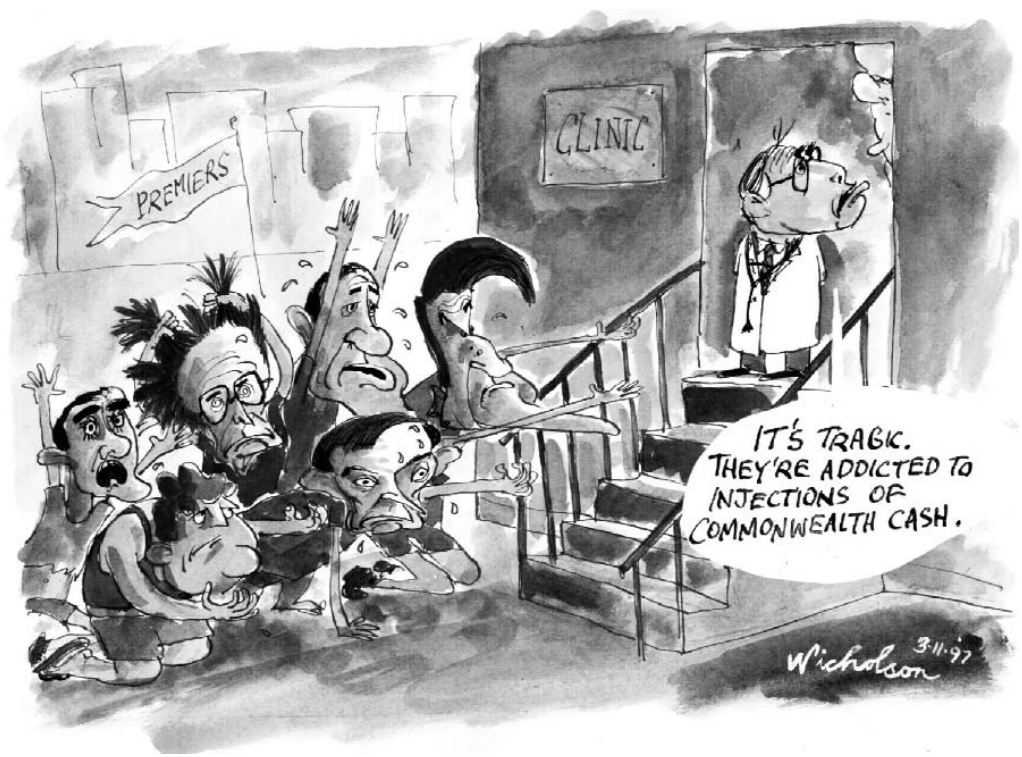

Source: Cartoon by Nicholson from The Australian dated November 3, 1997. www.nicholsoncartoons.com.au

\section{Bridging Vertical Fiscal Gaps}

The terms vertical fiscal gap and vertical fiscal imbalance have been mistakenly used interchangeably in recent literature on fiscal decentralization. A vertical fiscal gap is defined as the revenue deficiency 
arising from a mismatch between revenue means and expenditure needs, typically of lower orders of government. A national government may have more revenues than warranted by its direct and indirect spending responsibilities; regional and local governments may have less revenues than their expenditure responsibilities.

A vertical fiscal imbalance occurs when the vertical fiscal gap is not adequately addressed by the reassignment of responsibilities or by fiscal transfers and other means. Boadway (2002b) argues that vertical fiscal imbalance incorporates an ideal or optimum view of expenditures by different orders of government and is therefore hard to measure.

Vertical fiscal gap may arise due to (a) inappropriate assignment of responsibilities; or (b) centralization of taxing powers; or (c) pursuit of beggar-thy-neighbor tax policies (wasteful tax competition) by subnational governments; and (d) lack of tax room at subantional levels due to heavier tax burdens imposed by the central government. To deal with the vertical fiscal gap, it is important to deal with its sources through a combination of policies such as the reassignment of responsibilities, tax decentralization or tax abatement by the center and tax-base sharing (by allowing subnational governments to levy supplementary rates on a national tax base). Only as a last resort should revenue sharing, or unconditional formula-based transfers, all of which weaken accountability to local taxpayers, be considered to deal with this gap. Taxation by tax-sharing, as practiced in China and India, is particularly undesirable, as it creates incentives for donors to exert less effort in collecting taxes that are shared than they would collecting taxes that are fully retained. In industrial countries the fiscal gap is usually dealt with by tax decentralization or taxbase sharing. Canada and the Nordic countries have achieved harmonized personal and corporate income tax systems by allowing the central government to provide tax abatement and subnational governments to impose supplementary rates on the national tax base. In developing countries and transition economies, both tax by tax sharing and general revenue sharing are typically used to deal with the fiscal gap.

A number of countries, including China, India, Malaysia, Pakistan, Sri Lanka and South Africa, have in the past, provided deficit grants to fill fiscal gaps at subnational levels - with unwelcome results in terms of mushrooming of subnational deficits. These grants are still in vogue in China, Hungary, and South Africa. 


\section{Bridging the Fiscal Divide through Fiscal Equalization Transfers}

Fiscal equalization transfers are advocated to deal with regional fiscal equity concerns. These transfers are justified on political and economic considerations.

Large regional fiscal disparities can be politically divisive and may even create threats of secession (Shankar and Shah 2003). This threat is quite real: since 1975 about 40 new countries have been created by the break-up of existing political unions. Fiscal equalization transfers could forestall such threats and create a sense of political participation, as demonstrated by the impact of such transfers on the separatist movement in Quebec, Canada.

Decentralized decisionmaking results in differential net fiscal benefits (imputed benefits from public spending minus tax burden) for citizens depending on the fiscal capacities of their place of residence. This leads to both fiscal inequity and fiscal inefficiency in resource allocation. Fiscal inequity arises as citizens with identical incomes are treated differently depending on their place of residence. Fiscal inefficiency in resource allocation results from people in their relocation decisions comparing gross income (private income plus net public sector benefits minus cost of moving) at new locations; economic efficiency considerations warrant comparing private income minus moving costs only without any regard to public sector benefits. A nation that values horizontal equity (the equal treatment of all citizens nationwide) and fiscal efficiency needs to correct the fiscal inequity and inefficiency that naturally arise in a decentralized government. Grants from the central government to states and/or local governments can eliminate these differences in net fiscal benefits if the transfers depend on the tax capacity of each state relative to others and on the relative need for and cost of providing public services. The more decentralized the tax system is, the greater the need for equalizing transfers.

The elimination of net fiscal benefits requires a comprehensive fiscal equalization program that equalizes fiscal capacity (the ability to raise revenues from own basis using national average tax rates) to a national average standard and provides compensation for differential expenditure needs and costs due to inherent cost disabilities rather than differences that reflect different policies. Some economists argue that if public sector tax burdens and service benefits are fully capitalized in property values, the case for fiscal equalization transfers is weaker, as 
residents in rich states pay more for private services and less for public services and vice versa in poorer states. According to this view, as argued by Oates (1982), fiscal equalization is a matter of political taste. This view has gained currency at the federal level in the United States and explains why there is no federal fiscal equalization program there. In contrast, local fiscal equalization drives most state assistance to local governments in the USA, especially school finance (Box 1.2).

\section{Box 1.2 Financing Schools in the United States}

U.S. states have taken various approaches to school finance. The states of Hawaii, Idaho, and Washington fully finance primary and secondary education. In contrast, New Hampshire covers only 9 percent of school finance.

Delaware and North Carolina finance education through bloc grants that are indexed to population, GDP, and inflation growth rates. The grants are derived by calculating equal amounts per unit based on the number of students, teachers, classrooms, courses, classes, and other factors. The units can be standardized using various yardsticks, such as class size and teacher: pupil ratios. Various measures of students, including enrollment, average daily attendance, enrollment weighted by grades, types of programs, and number of students with special needs, are used.

Other states use equalization grants, including foundation grants, percentage equalization grants, and district power equalization grants.

Foundation grants vary inversely with the fiscal capacity of a school board. The grant allocation is based on an application of the representative tax system approach to fiscal capacity equalization per student across school districts. The following formula is used:

foundation grant $=$ (maximum per student grant - own school district contribution per student based on mandated minimum tax rate applied to per student tax base) $\mathrm{x}$ enrollment

Forty-two states have adopted variants of this approach, with 22 states specifying the minimum mandated tax rate. Various measures are used to determine enrollment, including the number of students on the rolls on a specified date, average daily attendance, and average attendance over a period. Most states (36) use a scheme that weights enrollment by grade, program, and student disabilities. 
Rhode Island uses a percentage equalization grant - a matching cum equalization grant for school spending based on the following formula:

grant per student $=[1-$ matching rate $\mathrm{x}$ (per capita tax capacity in the district/ state average district tax capacity per capita)] $\mathrm{x}$ district spending per capita

District power equalization grants, used in Indiana and Washington, include incentives for increased tax effort in an equalizing grant. The formula used is:

grant $=$ (per capita average fiscal capacity - per capita fiscal capacity of the district) $\mathrm{x}$ district tax rate

Source: Vaillancourt (1998).

Conceptually, full capitalization requires a small open area with costless mobility. Most federations and even states in large countries do not fulfill this condition. As a result, criticism of fiscal equalization using the capitalization argument may have only weak empirical support (Shah, 1988a).

In principle, a properly designed fiscal equalization transfers program corrects distortions that may cause fiscally induced migration by equalizing net fiscal benefits across states. A reasonable estimate of the costs and benefits of providing public services in various states is essential to measure net fiscal benefits. Measures of differential revenue-raising abilities and the needs and costs of providing public services in different states must be developed. Equalization of net fiscal benefits could then be attempted by adopting a standard of equalization and establishing the means of financing the needed transfers.

\section{Measuring Fiscal Capacity}

Estimating fiscal capacity - the ability of governmental units to raise revenues from their own sources - is conceptually and empirically difficult. The two most common ways of doing so are with macroeconomic indicators and the representative tax system.

Various measures of income and output serve as indicators of the ability of residents of a state to bear tax burdens. Among the better known measures are the following: 
- State gross domestic product (GDP). State GDP represents the total value of goods and services produced within a state. It is an imperfect guide to the ability of a state government to raise taxes, since a significant portion of income may accrue to nonresident owners of factors of production. For example, the Northern Territory has the highest per capita income in Australia, but it is treated as the poorest jurisdiction in federal-state fiscal relations.

- State factor income. State factor income includes all income - capital and labor- earned in the state. It makes no distinction between income earned and income retained by residents.

- State factor income accruing to residents only. This measure represents a more useful measure, provided states are able to tax factor income.

- State personal income. The sum of all income received by residents of a state is a reasonable measure of the state's ability to bear tax burdens. It is an imperfect and partial measure of the ability to impose tax burdens, however, and therefore not a satisfactory measure of overall fiscal capacity.

- Personal disposable income. Personal disposable income equals personal income minus direct and indirect taxes plus transfers. This concept is subject to the same limitations affecting personal income.

In general, macro measures do not reflect the ability of subnational governments to raise revenues from own sources. Boadway argues against the use of macro indicators in an equalization formula on the grounds that a macro formula "ignores the fact that fiscal inefficiency and fiscal inequity are the products of the actual mix of taxes chosen by provincial governments" (Boadway, 2002a, 12). This neglect runs the risk of violating the principles of equalization itself. A second major difficulty in the use of macro indicators is the availability of accurate and timely data at subnational levels. Such data become available only with significant lags, and the accuracy of such data may be questionable. Use of these data may therefore invite controversy (see Aubut and Vaillancourt 2001 for a Canadian illustration of this point). Despite these problems, both Brazil and India use macro indicators in their federal-state revenue-sharing programs.

The representative tax system approach measures the fiscal capacity of a state by the revenue that could be raised if the government employed all of the standard sources at the nationwide average intensity of use. 
Estimating equalization entitlements using the representative tax system requires information on the tax bases and tax revenues for each state. Fiscal capacity of the have-not states is brought up to the median, mean, or other norm. Using the mean of all states as a standard, the state equalization entitlement for a revenue source is determined by the formula:

$$
E_{x}^{i}=(P O P)_{x}\left\{\left[(P C T B)_{n a}^{i} \times t_{n a}^{i}\right]-\left[(P C T B)_{x}^{i} \times t_{n a}^{i}\right]\right\}
$$

where $E^{i}$ is the equalization entitlement of state $x$ from revenue source $i, P O P$ is population, $P C T B^{i}$ is the per capita tax base of revenue source $i, t^{i}$ is the national average tax rate of revenue source $i$, subscript $n a$ is the national average, and subscript $x$ is state $x$. The equalization entitlement for a state from a particular revenue source can be negative, positive, or zero. The total of these values indicates whether a state receives a positive or negative entitlement from the interstate revenuesharing pool. Since data on major tax bases and tax collections required to implement representative tax system are usually published regularly by various levels of government, the representative tax system does not impose new data requirements and can be readily implemented in countries that have decentralized taxing responsibility to subnational levels, as most transition economies do. Of course, implementing such a system will not be feasible in countries with limited tax decentralization (very large vertical fiscal gaps) or poor tax administration.

\section{Measuring Expenditure Needs}

The case for fiscal equalization rests on eliminating different net fiscal benefits across states that give rise to fiscally induced migration. Such differential net fiscal benefits can arise as a result of decentralization of taxing authority and decentralized public expenditures. Differences in the demographic composition of the population across jurisdictions will result in differential needs for decentralized public services, such as education, health and social welfare. Differences in age distribution affect the need for schools, hospitals, and recreational facilities. Differences in the incidence of poverty and disease may affect the need for education, training, health, social services, and transfer payments. Jurisdictions with higher need factors would have greater need for revenues to provide comparable levels of public services at comparable levels of taxation. These need differentials are likely to cause substantial variations across 
jurisdictions in the level and mix of public goods provided, resulting in different net fiscal benefits A strong case for equalization can be established on grounds of efficiency and equity to compensate for need differentials that give rise to different net fiscal benefits.

The fiscal federalism literature treats differential costs as synonymous with differential needs, but some cost differences may arise from deliberate policy decisions by subnational governments rather than differences in need. Boadway (2004) argues that even for inherent cost disadvantages, such as differences between urban and rural areas, the equity advantage of more equal provision must be weighed against the efficiency costs. If it is more costly to deliver public services in rural areas than urban areas, it is inefficient for an equalization program to neutralize these cost differences. Even in unitary states, the level of public services in remote, rural, or mountainous areas is usually lower than in more densely populated urban areas. Under a decentralized fiscal system, a policy choice must be made about minimum standards, but there is no justification for providing the same level of services in remote and urban areas, as the Australian fiscal need equalization program does. Instead, as Boadway suggests, one could stratify locations in all regions by their costs and equalize across regions within comparable strata. Equalization grants should partially offset only inherent disabilities, disregarding cost differences that reflect deliberate policy decisions or differences in the efficiency with which resources are used.

In practice, expenditure need is more difficult to define and derive than fiscal capacity. The difficulties include defining an equalization standard; understanding differences in demographics, service areas, populations, local needs, and policies; and understanding strategic behavior of recipient states. Despite these formidable difficulties, numerous attempts have been made to measure expenditure need. The approaches can be broadly classified into three main categories: (a) ad hoc determination of expenditure needs, (b) representative expenditure system using direct imputation methods, and (c) the theory-based representative expenditure system.

(a) Ad hoc determination of expenditure needs uses simple measures of expenditure needs in general-purpose transfers. The factors used and their relative weights are arbitrarily determined. Germany uses population size and population density adjustments, China uses the number of public employees, India uses measures of backwardness.

The Canadian provinces use simple measures of expenditure need in their general-purpose transfers to municipalities These include 
population size, population density, population growth factors, road length, number of dwelling units, location factors (such as northern location), urbanization factors (primary urban population and urban/rural class) and social assistance payments (see Shah 1994b). The most sophisticated of these approaches is the one taken by Saskatchewan, where the standard municipal expenditure of a class of municipalities is assumed to be a function of the total population of the class. Regression analysis is used to derive a graduated standard per capita expenditure table for municipal governments by population class.

An interesting example of the application of this approach is South Africa's use of it in its equitable share transfers to the provinces (South Africa 2006). The equitable share formula applicable for 2006-08 focuses almost entirely on need factors, with only a 1 percent weight given to negative needs (per capita GDP). The formula uses the following shares:

- A basic share (14 percent weight) is derived from each province's share of the national population.

- An education share (51 percent) is based on the size of the school-age population (5-17) and the average number of learners (grades R-12) enrolled in public ordinary schools over the past three years.

- A health share (26 percent) is based on the proportion of the population with and without access to medical aid.

- An institutional component (5 percent) is divided equally among the provinces.

- A poverty component ( 3 percent) is based on incidence of poverty.

- An economic output component (1 percent) is based on data on GDP by region.

(b) The representative expenditure system using direct imputation methods seeks to create a parallel system to the representative tax system on the expenditure side. This is done by dividing subnational expenditures into various functions, determining total expenditures by each jurisdiction for each function, identifying relative need/cost factors, assigning relative weights using direct imputation methods or regression analysis, and allocating total expenditures of all jurisdictions on each function across jurisdictions on the basis of their relative costs and needs for each function (see table 1.3 for a compilation of need factors used in industrial countries). 


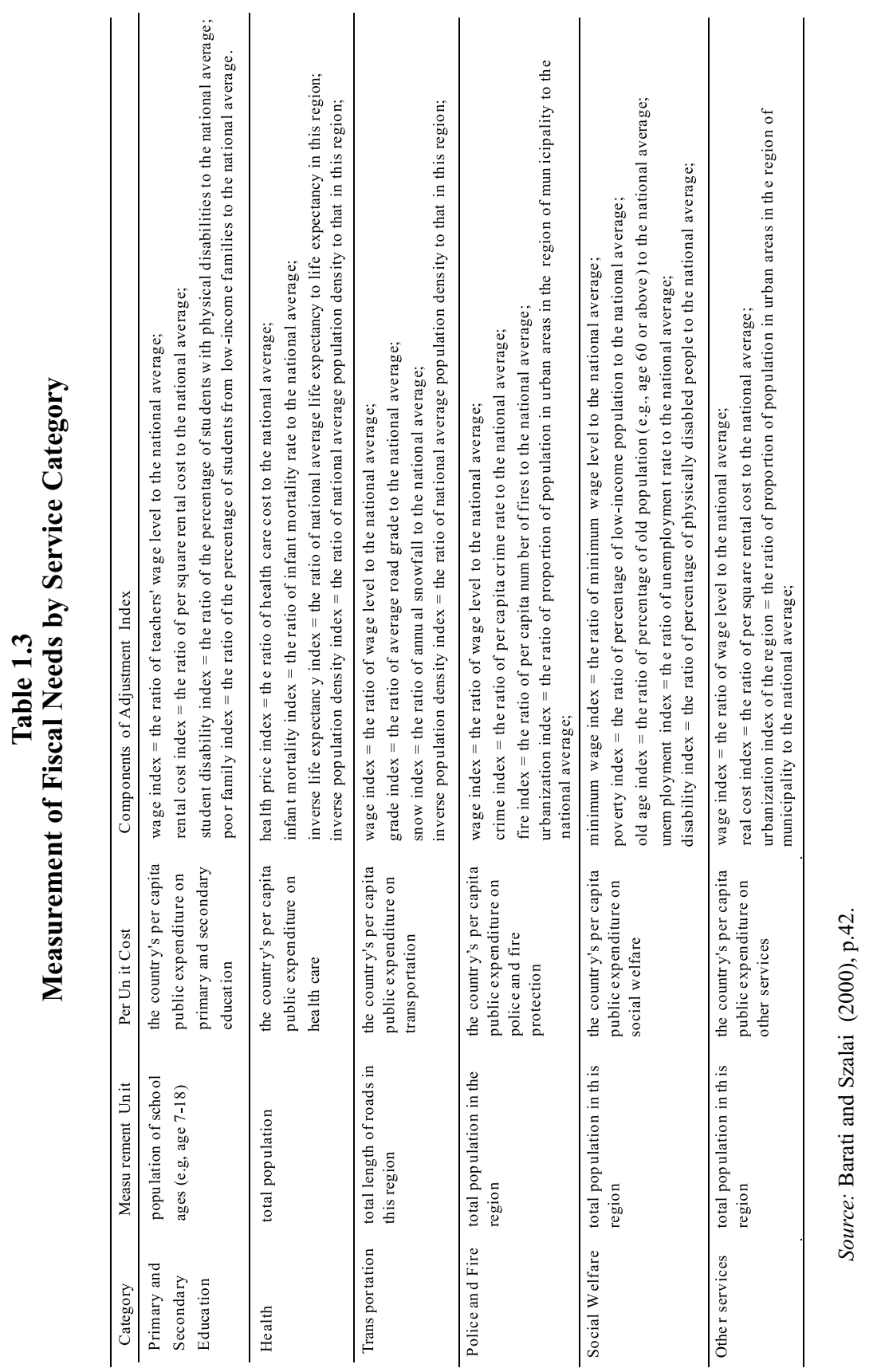


The advantage of this approach is that it obviates the need for the very elaborate calculations and assumptions needed to quantify the provision of services at some defined level. It does so by using the sum of actual total expenditures as the point of departure for measuring expenditure needs, reducing the problem to one of allocating total need among subnational governments on the basis of selected indicators of need, including proxies for need if desired. The disadvantage of this approach is that it does not necessarily exclude expenses incurred by any of the provinces that go beyond the concept of a "reasonable level of public service". However, the approach can be adjusted to exclude identifiable excesses from total expenditures (for example gold standards for some services or relatively unafforadble benefits provided by some rich states) in respect of which needs are to be allocated.

A sophisticated variant of this methodology is used by the Commonwealth Grants Commission of Australia, which defines expenditure as the cost of supplying average performance levels for the existing mix of state-local programs. Relative expenditure needs are then determined empirically using direct imputation methods for 41 state-local expenditures. The following hypothetical example illustrates the treatment of welfare expenditures using a crude approach similar to that used by the Commonwealth Grants Commission for establishing expenditure needs under a representative expenditure system.

Assume that there are 10 states in Grantland, that the unit costs of welfare are equal in all states, and that needs for welfare vary based on the percentage of the working-age population that is unemployed, the percentage of the population that is not of working age, and the percentage of families with a single parent. The independent grants commission assigns a 40 percent weight to the percentage of the working-age population that is unemployed, a 35 percent weight to the percentage of the population that is not of working age, and a 25 percent weight to the percentage of families with a single parent. Assume that expenditures by all states for welfare total $\$ 5$ billion and that state $A$ accounts for 4.8 percent of the 10state total for the first factor, 3.0 percent of the total for the second factor, and 2.2 percent of the total for the third factor. State $A$ 's estimated need for a standard level of welfare expenditure would then equal:

$\$ 5$ billion $\mathrm{x}(0.048 \times 0.40)+(0.03 \times 0.35)+(0.022 \times 0.25)=\$ 176$ million, or 3.2 percent of all state expenditures.

Shah (1994a) provides an application of the approach using provincial-local expenditure functions for Canada and uses quantitative analysis in selection and weighting of factors for various 1 expenditure functions (see Table 1.4). 
Table 1.4

Weighting of factors for provincial-local expenditure functions for Canada

\begin{tabular}{|c|c|c|}
\hline Expenditure Category & Need/Cost Factors & $\begin{array}{l}\text { Relative } \\
\text { Weights }\end{array}$ \\
\hline \multirow{6}{*}{$\begin{array}{l}\text { Trans portation \& } \\
\text { Commun ications }\end{array}$} & Snowfall (Annual - in centimeters) SNOW & 0.1020 \\
\hline & Highway Construction Price Index (HCPI) & 0.6580 \\
\hline & $\begin{array}{l}\text { Paved roads and streets per square kilometer of } \\
\text { area (RSPR) }\end{array}$ & 0.0005 \\
\hline & $\begin{array}{l}\text { Non-cultiva table area as a proportion of total } \\
\text { area (NCAR) }\end{array}$ & $\begin{array}{l}0.2357 \\
1.0000\end{array}$ \\
\hline & & \\
\hline & $\begin{array}{l}\text { Index }=(0.10 * \text { ISNOW }+0.66 * \text { IHC PI }+ \\
0.0005 * \text { IRSPR }+0.24 * \text { INCAR }) * \text { IS RP }\end{array}$ & \\
\hline \multirow{7}{*}{$\begin{array}{l}\text { Post-Secondary Education } \\
\text { (PSE) }\end{array}$} & Full time enrollment in grade $13+(000)(\mathrm{P}$ SS $)$ & 0.048 \\
\hline & $\begin{array}{l}\text { Percentage of Population having a minority } \\
\text { language as mother tongue (M L) }\end{array}$ & 0.19 \\
\hline & Provincial Unem ployment Rate (UR) & 0.018 \\
\hline & Education Price Index (EP I) & 0.717 \\
\hline & Help Wanted Index (HWI) & 0.010 \\
\hline & Foreign Post-Secondary Students (FPS) & 0.017 \\
\hline & $\begin{array}{l}\text { Total } \\
\text { Index }=\left(0.18^{*} \text { IPSS }+.70 * \text { IML }+.08 * \text { IUR }+\right. \\
.04 * \text { IFPS }) * \text { IHWI*IEP I }\end{array}$ & 1.000 \\
\hline \multirow{4}{*}{$\begin{array}{l}\text { Elementary and Secondary } \\
\text { Education (ESE) }\end{array}$} & Population under 18 (PO17) & 0.014 \\
\hline & Population Density (PD) & 0.017 \\
\hline & Education Price Index (EP I) & 0.969 \\
\hline & $\begin{array}{l}\text { Total } \\
\text { Index }=(.02 * \text { IPD }+, 98 * \text { IEP I }) * \text { IP017 }\end{array}$ & 1.000 \\
\hline \multirow[t]{3}{*}{ Health (HE) } & $\begin{array}{l}\text { Alcoholism (Hospital separations for Alcohol } \\
\text { related cases) (ALCO) }\end{array}$ & 0.123 \\
\hline & Urban Population (PU) & 0.877 \\
\hline & $\begin{array}{l}\text { Total } \\
\text { Index }=(0.123 * \text { IALCO }+0.877 * \text { IPU })\end{array}$ & 1.000 \\
\hline Social Services (SS) & Single Parent Families (SPF) & 1.00 \\
\hline \multirow[t]{3}{*}{ Police Protection } & Criminal Code Offenses (CC O) & 0.39 \\
\hline & $\begin{array}{l}\text { Proportion of Population in Metropolitan } \\
\text { (PMAR) Areas }\end{array}$ & 0.61 \\
\hline & $\begin{array}{l}\text { Total } \\
\text { Index }=(.39 * \text { ICCO }+.61 * \text { IPM AR })\end{array}$ & 1.00 \\
\hline \multirow[t]{6}{*}{ General Services (GS) } & $\begin{array}{l}\text { Private sector wa ges (Industrial composite) } \\
\text { (AMW) }\end{array}$ & 0.769 \\
\hline & $\begin{array}{l}\text { Percen tage of population having a minority } \\
\text { language as mother tongue (M L) }\end{array}$ & 0.001 \\
\hline & Population Density (PD) & 0.023 \\
\hline & Population (POP F) & 0.039 \\
\hline & Snowfall (Annual - in centimeters) (SNOW) & 0.168 \\
\hline & $\begin{array}{l}\text { Total } \\
\text { Index }=(.001 * \mathrm{M} \mathrm{L}+0.175 * \text { ISNO W }+0.80 * \text { IAMW }+ \\
.024 * \text { IPD }) * \text { IPOP F }\end{array}$ & 1.000 \\
\hline
\end{tabular}

Note: Calculations based on regression coefficients. The use of a variable prefixed by I means that a relative index of the variable is used. 
This approach is highly subjective and therefore potentially controversial. Recent experience in Australia vividly demonstrates the problems that arise if such an approach is followed in practice as discussed in the following section. Some subjectivity and imprecision can be alleviated by using quantitative analysis in choosing factors and weights, as Shah suggests (1994a).

(c) The Theory-based representative expenditure system. The representative expenditure system can be significantly improved using a conceptual framework that embodies appropriately defined concept of fiscal need and properly specified expenditure functions that are estimated using objective quantitative analysis, as proposed by Shah (1996) for Canada. Under this refined approach, the so-called the theory-based representative expenditure system, the equalization entitlement from expenditure category $i$ equals the per capita potential expenditure of state $A$ for category $i$ based on own need factors if it had national average fiscal capacity minus per capita potential expenditure of state $A$ on expenditure category $i$ if it had national average need factors and national average fiscal capacity.

This approach is even more difficult to implement than the less refined approach, but it has the advantage of objectivity and it enables the analyst to derive measures based on actual observed behavior rather than ad hoc value judgments. The relative weights assigned to various need factors and their impact on allocation of grant funds are determined by econometric analysis. Furthermore, this approach yields both the total pool and the allocation of fiscal need equalization grants among recipient units. This method requires specifying determinants for each service category, including relevant fiscal capacity and public service need variables. A properly specified regression equation yields quantitative estimates of the influence each factor has in determining spending levels of a category of public service. This information can be analyzed to determine what each state would actually have spent if it had national average fiscal capacity and but actual need factors. This then can be compared to the standard expenditure for each service based upon an evaluation of the same equation for determining what each state would have spent if it had the national average fiscal capacity and also national average need factors. The sum of differences of these two expressions for all expenditure categories would determine whether or not the state had more (if sum was positive) or less than the average needs (if sum was negative) (see Shah 1996 for a Canadian application of this approach). 
The formula for equalization entitlement based on expenditure classification $i$ for state $\mathrm{x}$ could be stated as follows:

$$
E E_{x}^{i}=(P O P)_{x}\left[(P C S E)_{x}^{i}-(P C S E){ }_{n a}^{i}\right]
$$

where $E E_{x}^{i}$ is the equalization entitlement for expenditure classification $i$ for state $x, P O P_{x}$ is the population of state $x, P C S E_{x}^{i}$ is the per capita standardized expenditure by state $x$ on expenditure classification $i$ (or the estimated amount the state would have spent to meet actual needs if it had national average fiscal capacity), and PCSE ${ }_{n a}$ is the national average per capita standardized expenditure for classification $i$. This is the estimated expenditure for all states, based on national average values of fiscal capacity and need. The equalization entitlement for a particular expenditure classification could be positive, negative, or zero. The total of these entitlements in all expenditure categories is considered for equalization.

A comprehensive system of equalization determines the overall entitlement of a state by considering its separate entitlements from the representative tax system and the representative expenditure system. Only states with positive net entitlements are eligible for transfers of all or some fraction of the total amount, with the fraction determined by the central government based on the availability of funds.

\section{Practical Difficulties in Equalizing Expenditure Needs: Australia's Experience}

The Commonwealth Grants Commission of Australia found the theory-based representative expenditure system approach difficult to implement. It opted instead for an alternate representative expenditure system using direct imputation methods that simply equalizes what all states on average actually spend. The Australian system seeks absolute comparability for all 41 state-local services rather than just merit goods (some would question whether this is worth pursuing).

Australia's approach raises several questions. Is equal access to all services in remote areas desirable at any cost? If a rich state decides to buy limousines for its officials, or make higher welfare payments to its aboriginal population, why should equalization payments to poorer states go up? Such an approach diverts states' energies to demonstrate that they 
"need more to do less" or "money does not buy much" as opposed to "doing more with less" as higher spending is rewarded and cost-saving in delivering improved services is discouraged by the equalization grant formula. Such a system rewards some bad behaviors, including excessive use of some services by specific groups, tax expenditures by states to attract capital and labor, and state assumption of contingent and noncontingent liabilities.

In addition to conceptual difficulties, the Australian program is plagued with measurement problems. The determinants of expenditure needs for various expenditure categories are arrived at based on broad judgments. Arbitrary procedures are used to derive factor weights and combine various factors into functional forms. State disabilities stemming from various factors are multiplied. For highly correlated factors, disabilities are artificially magnified through double counting and multiplication. The Australian experience highlights the practical difficulties associated with implementing fiscal need compensation as part of a comprehensive fiscal equalization approach (see Shah 2004).

\section{Conclusions regarding the Practice of Fiscal Need Equalization}

Fiscal capacity equalization is relatively straightforward to comprehend and feasible (with some difficulty) to implement once a (political) decision is made on the standard of equalization. Fiscal need equalization is a complex and potentially controversial proposition, because by its very nature it requires making subjective judgments and using imprecise analytical methods. An analytical approach such as regression analysis using historical data is inappropriate when underlying structures are subject to change due to technology and other dynamic considerations. Great care is needed to specify determinants of each service.

Australia's Commonwealth Grants Commission makes these calculations using broad judgments and sampling services. With the single exception of the Northern Territory, which has a large aboriginal population, there is little cross-state variations in the expenditure needs of the Australian states. A special grant for the Northern Territory would simplify the Australian program while achieving its equalization objectives.

Very few countries opt for a comprehensive program of fiscal equalization. In contrast, a few industrial countries use fiscal capacity equalization programs, both at the federal-state (Canada, Switzerland) and 
state-local levels (Canada, Sweden, Switzerland, Denmark). Fiscal need compensation is important, but for the sake of simplicity and objectivity, rather than implement a fiscal need equalization approach as part of the fiscal equalization program, it may be better instead to achieve fiscal needs compensation on a service by service basis through output-based national minimum standards grants. South Africa, however, as discussed earlier, does not use output-based transfers and instead compensates for fiscal needs on a service-by-service basis in determining provincial entitlements for central general-purpose grants to the provinces.

\section{Frequently Encountered Concerns in Designing Equalization Transfers}

The most frequently encountered concerns in designing equalization transfers include: defining the equalization standard, whether or not to include tax efforts provisions, how to ensure stability and forestalling strategic behaviors to qualify for higher level of transfers. These issues are discussed in the following paragraphs.

Equalizing net fiscal benefits requires an explicit standard of equalization - the level to which each state is entitled to be raised to provide public sector net benefits per household that are comparable to other states. Simplicity dictates choosing either the mean or the median of the governmental units involved as the standard. The mean provides a good representation of the data as long as outliers are not present. If sample values have a wide range, the median, or the mean after eliminating outliers, provides a better representation of the sample. The mean is preferable to the median, however, for ease of computation.

An ideal fiscal equalization program is self-financing. Member governments are assessed, as in Germany, positive and negative entitlements that total zero, with the federal government acting as a conduit. If an interstate equalization pool creates administrative difficulties, the equalization program can be financed out of general federal revenues, as done in Canada, derived in part from the states receiving equalization.

There is general consensus in the academic literature that an equalization system should enable state governments to provide a standard package of public services if the government imposes a standard level of taxes on the bases at its disposal. State governments or their citizens 
should, however, be permitted to substitute lower rates of taxation for lower levels of services. In such cases, the equalization payments should be in the form of unconditional grants, which have only income effects. Service areas in which there is a good reason to set minimum national standards are better handled by output-based conditional grants and shared-cost programs. By raising a state's fiscal capacity, unconditional equalization grants enable poorer states to participate in shared-cost programs more easily.

Incorporating tax effort into the formula for determining equalization involves making the equalization entitlement a function of the ratio of actual tax collections in a state to the state's base. Potential nonrecipient states may wish to see such a factor incorporated into the program to prevent states with a positive fiscal deficiency in an area from collecting equalization payments even if they may not levy a tax in the area. Potential recipient states may wish to see tax effort incorporated because without it, extra tax effort on their part will be relatively unproductive compared with a wealthy state.

Several problems exist with incorporating tax effort into the program:

- The inclusion of tax effort will cause the program to depart from its unconditional nature. A state should be free to substitute grant funds for revenue from own sources.

- If a state raises taxes to provide a package of services that is more costly than the standard, it should not receive equalization for doing so; other states should not have to pay most of the cost if a state decides to paint its roads.

- Incorporating tax effort ties the federal government to the expenditure philosophies of the various states.

- Some states do not have tax bases in all areas.

- Incorporating tax effort may encourage the employment of strategy by a state.

- In view of the different abilities of the states to export taxes, the measurement of tax effort would be crude.

- Incorporating tax effort could result in an increase in taxes on the poor states. 
In view of these considerations, including tax effort would not improve a program of equalization payments.

If equalization payments are based on relative measures of fiscal capacity, they should have a stabilizing effect on state revenues. The level of payments will move in the opposite direction of states' own revenueraising capacity. Maximum stabilization of state-local revenues will occur when payments are based on all revenue sources, a national average standard of equalization is used, cyclical fluctuations in provincial economies are small, and the time lag in calculating the grants is relatively short. When any large component of the total base, such as natural resource revenues, is volatile, the destabilizing effects can be large. In this case, some sort of averaging formula should be used to ease difficulties associated with provincial budgeting in the face of uncertainty.

Strategy refers to action provincial/state governments can take to influence the level of payments they receive. A program that enables a state to employ strategy is undesirable, because in general the extra payments received may not have any relation to actual disparities. For example, a program employing tax effort could enable states to raise their entitlements by imposing heavy taxes in areas in which they have a tax base below the national average. This problem is less serious in practice than one might expect, since room for additional taxation from sources in which the potential have-not states are not well endowed is extremely limited.

\section{Reflections on Comparative Practices of Fiscal Equalization Transfers}

A small but growing number of industrial countries and transition economies have introduced fiscal equalization programs. These include Australia, Canada, China, Denmark, Germany, Indonesia, Latvia, Lithuania, Poland, the Russian Federation, Sweden, Switzerland, and Ukraine. All equalization programs are concerned with interjurisdictional equity or horizontal fiscal equity, not interpersonal (vertical) equity. Which level of government finances and administers an equalization program is determined either by the constitution (as in Canada, Germany, and Switzerland) or by the legislature (as in Australia) (Table 1.5). 
Table 1.5

Features of Fiscal Equalization Transfers in Selected Countries

\begin{tabular}{|c|c|c|c|c|}
\hline Feature & Australia & Canada & Germany & Switzerland \\
\hline Objective & $\begin{array}{l}\text { Build capacity to } \\
\text { provide services } \\
\text { at same standard } \\
\text { with same } \\
\text { revenue effort } \\
\text { and same } \\
\text { operational } \\
\text { efficiency }\end{array}$ & $\begin{array}{l}\text { Achieve } \\
\text { reasona bly } \\
\text { compara ble levels } \\
\text { of public services } \\
\text { at reasonably } \\
\text { comparable levels } \\
\text { of taxation across } \\
\text { provinces }\end{array}$ & $\begin{array}{l}\text { Equalize } \\
\text { differences in } \\
\text { financial capacity } \\
\text { of states }\end{array}$ & $\begin{array}{l}\text { Provide } \\
\text { minimum } \\
\text { acceptable levels } \\
\text { of certain public } \\
\text { services without } \\
\text { much heavier tax } \\
\text { burdens in some } \\
\text { cantons than } \\
\text { others }\end{array}$ \\
\hline Legal status & Federal law & Constitution & Constitution & Constitution \\
\hline Legislation & $\begin{array}{l}\text { Federal } \\
\text { parliament }\end{array}$ & Federal parliament & $\begin{array}{l}\text { Federal } \\
\text { parliament, } \\
\text { initiated by the } \\
\text { upper house } \\
\text { (Bundesrat) }\end{array}$ & $\begin{array}{l}\text { Federal } \\
\text { parliament }\end{array}$ \\
\hline $\begin{array}{l}\text { Paternal or } \\
\text { fraternal }\end{array}$ & Paternal & Paternal & Fraternal & Mixed \\
\hline $\begin{array}{l}\text { Total pool } \\
\text { determination }\end{array}$ & Adhoc & Formula & Formula & Adhoc \\
\hline $\begin{array}{l}\text { Equalization } \\
\text { standard } \\
\text { determines pool } \\
\text { and allocation }\end{array}$ & No & Yes & Yes & No \\
\hline Allocation & Formula & Formula & Formula & Formula \\
\hline $\begin{array}{l}\text { Fiscal capacity } \\
\text { equalization }\end{array}$ & $\begin{array}{l}\text { Yes, } \\
\text { representative tax } \\
\text { system }\end{array}$ & $\begin{array}{l}\text { Yes, representative } \\
\text { tax system }\end{array}$ & $\begin{array}{l}\text { Yes, actual } \\
\text { revenues }\end{array}$ & $\begin{array}{l}\text { Yes, major macro } \\
\text { tax bases }\end{array}$ \\
\hline $\begin{array}{l}\text { Fiscal need } \\
\text { equalization }\end{array}$ & Yes & No & $\begin{array}{l}\text { No (only } \\
\text { population size } \\
\text { and density) }\end{array}$ & Some \\
\hline $\begin{array}{l}\text { Program } \\
\text { complexity }\end{array}$ & High & Low & Low & Medium \\
\hline $\begin{array}{l}\text { Political } \\
\text { consensus }\end{array}$ & No (?) & Yes (?) & Yes (?) & Yes \\
\hline Who recommends & $\begin{array}{l}\text { Independent } \\
\text { agency }\end{array}$ & $\begin{array}{l}\text { Intergovernmental } \\
\text { committees }\end{array}$ & Solidarity Pact II & $\begin{array}{l}\text { Federal } \\
\text { government }\end{array}$ \\
\hline Sunset clause & No & Yes, five years & No & No \\
\hline Dispute resolution & Supreme Court & Supreme Court & $\begin{array}{l}\text { Constitutional } \\
\text { Court }\end{array}$ & Supreme Court \\
\hline
\end{tabular}

Source: Author.

Paternal programs, in which higher-level governments finance equalization at lower levels are common (examples include Australia and Canada). Fraternal or Robin Hood-type (Robin Hood stole from the rich to give to the poor) programs, in which governments at the same level establish a common pool, to which rich jurisdictions contribute and the 
poor jurisdictions draw, are rare (exceptions include Germany at the Länder level and Denmark at the local level). Robin Hood programs are preferred, as they represent an open political compromise balancing the interests of the union and the contributing jurisdictions, as done by the Solidarity Pact II in Germany. Such programs foster national unity, as poorer jurisdictions clearly see the contributions made for their well-being by residents of other jurisdictions. Paternal programs lack the discipline of fraternal programs, because unless enshrined in the constitution (as in Canada), they are guided largely by national politics and the budgetary situation of the federal and state/provincial (for local equalization) governments.

Some countries combine both Robin Hood (fraternal) and paternal components in their grant programs. In Switzerland, effective 2007, the federal government finances two-thirds of the program, with the remaining third financed by the rich cantons. The program has a fiscal capacity equalization component based on factor income, with 59 percent of the financing from the federal government and 41 percent from rich cantons. The cost equalization component is financed solely by the federal government. The German equalization program has a small supplementary component financed solely by the federal government. In Denmark equalization at the local level uses the Robin Hood approach for both fiscal capacity and fiscal need equalization for counties (using 85 percent national average standard) and large cities (90 percent and 60 percent of national average standards for fiscal capacity and fiscal need respectively ); for smaller municipalities, it uses the paternal approach for fiscal capacity equalization (using 50 percent of national average standard as the standard of equalization) and the Robin Hood approach for fiscal need equalization (using 35 percent of the national average as the standard of equalization).

Fiscal equalization programs also differ in terms of how the total pool of resources devoted to such programs is determined. In the Canadian and German programs, both the total pool and its allocation to provinces/states are formula driven. Under the Australian and Swiss programs, the total pool is arbitrarily determined by the federal government through an act of parliament - total proceeds of the general sales tax in Australia and an arbitrarily determined level of funding from the federal government and rich cantons in Switzerland.

The method of equalization also differs across programs. Australia, Canada, and Germany equalize per capita fiscal capacity using the representative tax system; Switzerland uses macro tax bases. It devotes 19 percent of equalization financing to cost equalization using eight factors: 
population size, area, population density, population older than 80 , number of large cities, number of foreign adults resident for more than 10 years, unemployment, and number of people requesting social assistance from the canton. In Germany actual rather than potential revenues are used in these calculations, as both actual and potential revenues are the same due to the uniformity of state tax bases and tax rates through federal legislation. It makes simple expenditure need adjustments based on population size, density and for harbour cities. China uses potential revenues although they equal actual revenues, when there is uniformity of tax bases and tax rates as mandated by central government legislation there. The Canadian program does not include fiscal need compensation. Australia uses a comprehensive equalization program, equalizing fiscal capacity as well as need for all state expenditures. Introduction of expenditure needs compensation introduces complexity and controversy and dilutes political consensus. As a result, the Australian program is the most complex and controversial of all programs and has garnered the least political consensus.

Most equalization programs are introduced as permanent programs; an exception is Canada, where there is a sunset clause for quinquennial review and renewal by the national parliament. Such a clause is helpful in providing a regular periodic evaluation and fine-tuning of the system. Almost all programs in mature federations specify formal mechanisms for resolving disputes regarding the working of these transfers programs.

Overall, the experience of mature federations with fiscal equalization suggests that in the interest of simplicity, transparency, and accountability, it would be better for such programs to focus only on fiscal capacity equalization to an explicit standard that determines the total pool as well as the allocation among recipient units. Fiscal need compensation is best dealt with through specific-purpose transfers for merit goods, as is done in most industrial countries.

Most transition economies have equalization components in their grant programs to subnational governments. China, Latvia, Lithuania, Poland, Romania, the Russian Federation, and Ukraine have adopted transfer formulas that explicitly incorporate either fiscal capacity and/or expenditure need equalization concerns. For local fiscal equalization, these countries nevertheless use one size fits all approaches to diverse forms of local government, creating equity concerns.

With the exception of Indonesia, developing countries have not implemented programs using explicit equalization standards, although 
equalization objectives are implicitly attempted in the general revenuesharing mechanisms used in Argentina, Brazil, Colombia, India, Nigeria, Mexico, Pakistan, and South Africa. These mechanisms typically combine diverse and conflicting objectives into the same formula and fall significantly short on individual objectives. Because the formulas lack explicit equalization standards, they fail to address regional equity objectives satisfactorily. Even in the Indonesian program total pool is not determined by an explicit equalization standard and instead equalization standard is implicitly determined by the ad hoc determination of total funds available for equalization purposes.

\section{Setting National Minimum Standards}

Setting national minimum standards in regional-local services may be important for two reasons. First, there is an advantage to the nation as a whole from such standards, which contribute to the free flow of goods, services, labor, and capital; reduce wasteful interjurisdictional expenditure competition; and improve the gains from trade from the internal common market. Second, these standards serve national equity objectives. Many public services provided at the subnational level, such as education, health, and social welfare, are redistributive in their intent, providing in kind redistribution to residents. In a federal system, lower-level provision of such services - while desirable for efficiency, preference matching, and accountability - creates difficulty fulfilling federal equity objectives. Factor mobility and tax competition create strong incentives for lowerlevel governments to underprovide such services and to restrict access to those most in need, such as the poor and the old. Attempts to exclude those most in need are justified by their greater susceptibility to disease and potentially greater risks for cost curtailment. Such perverse incentives can be alleviated by conditional nonmatching grants, in which the conditions reflect national efficiency and equity concerns and there is a financial penalty associated with failure to comply with any of the conditions. Conditions are thus imposed not on the specific use of grant funds but on attainment of standards in quality, access, and level of services. Such output-based grants do not affect local government incentives for cost efficiency, but they do encourage compliance with nationally specified standards for access and level of services. Properly designed conditional nonmatching output-based transfers can create incentives for innovative and competitive approaches to improved service delivery. Input-based grants fail to create such an accountability environment. 
With a few exceptions, noted below, both industrial and developing countries typically do not use output-based transfers for fiscal need compensation in sectoral grants. However, industrial countries typically keep the design of input-based conditional sectoral grants simple, using relatively simple demographic factors. In contrast, developing countries opt for complex formulas, using state of the art quantitative techniques (table 1.6).

A good illustration of a simple but effective output-based grant system is the Canadian Health Transfers program by the Federal Government of Canada. The program has enabled Canadian provinces to ensure universal access to high-quality health care to all residents regardless of their income or place of residence.

Under this program the federal government provides per capita transfers for health to the provinces, with the rate of growth of the transfers tied to the rate of growth of GDP. No conditions are imposed on spending, but strong conditions are imposed on access to health care. As part of the agreement to receive transfers from the federal government, the provinces undertake to abide by several access-related conditions:

1. Universality: All residents enjoy the same coverage.

2. Portability: Residents who move to another province retain health coverage in the province of origin for a transition period. Residents and nonresidents have equal access.

3. Public insurance but public/private provision: The province agrees to provide universal insurance to all. Both public and private providers are reimbursed from the public insurance system using the same schedule of payments, negotiated by the provincial medical association.

4. Opting in and opting out: Providers participating in the system cannot bill patients directly but are reimbursed by the province. All health care providers can opt out of the system, billing patients directly and not following the prescribed fee schedule. Patients of these providers are reimbursed according to a government schedule of payments by submitting claims.

5. No extra billing: Charges in excess of the prescribed schedule are not permitted by providers opting in the system. 
Table 1.6

Need Factors Used for Grant Financing of Health Care in Selected Countries

\begin{tabular}{|c|c|}
\hline Country name & Need Factors for Health Care Grants \\
\hline \multicolumn{2}{|c|}{ (a) Need based top-up for health car e in general grants } \\
\hline Belgium & Age, gender, unemployment, disability \\
\hline Finland (to local governments) & Age, disability, remoteness, local tax base \\
\hline Germany & Age, gender \\
\hline Netherlands & Age, gender, urbanization, income base \\
\hline Switzerland & Age, gender, region, income \\
\hline \multicolumn{2}{|c|}{ (b) Need-based specific purpose transfers for core health services } \\
\hline Denmark & Age, children of single parents \\
\hline England & $\begin{array}{l}\text { Age, sex, mortality, unemployment, elderly } \\
\text { livingalone }\end{array}$ \\
\hline France & Age \\
\hline Italy ( two-thirds ) & Age, gender, mortality \\
\hline North ern Ireland & Age, gender, mortality, low birth weight \\
\hline Norway (50 percent) & Age, gender, mortality, elderly living alone \\
\hline Portugal (15 percent) & $\begin{array}{l}\text { Burden ofillness: diabetes, hypertension, AIDS, } \\
\text { tuberculosis }\end{array}$ \\
\hline Scotland & Age, gender, mortality, rural costs \\
\hline Spain & Cross -boundary flows \\
\hline Sweden & Age, living alone, employment status, housing \\
\hline Wales & Age, gender, mortality, rural costs \\
\hline \multicolumn{2}{|c|}{ (c) Health transfers using composite indexes based upon principal component analysis } \\
\hline Brazil & $\begin{array}{l}\text { Infant mortality, } 1-64 \text { mortality, } 65+\text { mortality, } \\
\text { mortality rate by infectious and parasitic } \\
\text { diseases, mortality rate for neoplasia, mortality } \\
\text { rate for cardiovascular conditions, adolescent } \\
\text { mother percentage, illiteracy percentage, } \\
\text { percentage of homes without sanitati on, } \\
\text { percentage of homes without running water, } \\
\text { percentage of homes without garbage collection. }\end{array}$ \\
\hline South Africa & $\begin{array}{l}\text { Percentage female; percentage children under } 5 \text {; } \\
\text { percentage living in rural area; percentage older } \\
\text { than } 25 \text { without schooling; percentage } \\
\text { unemployed; percentage living in traditional } \\
\text { dwelling, shack or tent; percentage without } \\
\text { piped water in house or on site; percentage } \\
\text { without access to refuse disposal; percentage } \\
\text { without access to phone; percentage without } \\
\text { access to electricity; percentage living in } \\
\text { household headed by a woman. }\end{array}$ \\
\hline
\end{tabular}

Source: World Bank (2006). 
Breaches in any of these conditions results in penalties. If any of the first four conditions is breached, grant funding can be terminated. If the last condition is breached, grant funds are reduced on a dollar for dollar basis.

Developing countries and transition economies rarely use conditional nonmatching output-based transfers to ensure national minimum standards in merit goods or fiscal need compensation. There are nevertheless a few shining examples of programs that marry equity with performance orientation in grant allocation. These include central government transfers to provincial and local governments for primary education and transportation in Indonesia (discontinued in 2001); per pupil grants to all schools and a 25 percent additional grant as salary bonus for teachers in the best performing schools in Chile (Gonzalez 2005) and central grants to municipal governments to subsidize water and sewer use by the poor in Chile (Gomez-Lobo, 2002), central per capita transfers for education in Colombia and South Africa, and federal per pupil grants to states for secondary education and to municipalities for primary education in Brazil (Gordon and Vegas 2004).

Indonesian pre-2001 education and road maintenance grants to districts are examples of good grant design. The operating grant for schools in Indonesia used school-age population (7-12) as the criterion for distributing funds to district and town governments. These operating grants were supplemented by a matching capital grant for school construction (local government matching in the form of land for school) to achieve minimum standards of access to primary schooling - having primary school within walking distance to each community. The grants enabled Indonesia to achieve remarkable success in improving literacy and achieving minimum standards of access to primary education across the nation.

The Indonesian District/Town Road Improvement Grant (pre2001) used length of roads, condition, density (traffic use), and unit costs as criteria for distributing funds. This grant program helped monitor the health of the road network on a continuing basis and kept roads in good working conditions in most jurisdictions (Shah 1998).

In Chile and the State of Michigan in the United States, school grants finance vouchers for school-age children, giving parents choice in sending their children to public, private, or parochial schools. An additional performance grant of 25 percent is available to the best 
performing schools, for use as salary bonus to teachers in Chile. Grants to municipal governments in Chile for water and sewer access by the poor cover 25-85 percent (means tested) of a household's water and sewer bill for up to 15 cubic meters a month, with the client paying the rest (GomezLobo 2002).

Brazil has two noteworthy national minimum standards grant programs for primary education and health care. Under the 14th amendment to the federal constitution, state and municipal governments must contribute 15 percent of their two principal revenue sources (state value-added tax and state share of the federal revenue-sharing transfers for states, services tax, and the municipal share of the state revenuesharing transfers for municipalities) to the special fund for primary education (FUNDEF). If the sum of the state and municipal required contributions divided by the number of primary school students is less than the national standard, the federal government makes up the difference. FUNDEF funds are distributed among state and municipal providers on the basis of school enrollments.

Fiscal transfers in support of Brazil's Unified Health System, which operationalizes the constitutional obligation of the universal right to free health services, are administered under a federal program called Annual Budget Ceilings (TGF). The program has two components. Under the first component, equal per capita financing from the federal government that pass through states to municipalities is provided to cover basic health benefits. The second component provides federal financing for hospital and ambulatory care and all registered health care providers - state, municipal, and private - are eligible for grant financing through their municipal government. Under this grant, funding for hospital admissions and high-cost ambulatory care is subject to a ceiling for each type of treatment (World Bank, 2001).

Local governments in the Province of Alberta, Canada, use a novel approach to determine the allocation of taxpayers' contribution to school finance. Resident taxpayers designate the education component of their property tax bill to either public or parochial (religious, private) school boards. These declarations determine the total amount of property tax finance available to public and private providers. Schools receive grants on a per pupil basis, and parents retain the option to send their children to a school of their choosing regardless of the designation of school board on their tax return. This approach encourages competition among schools 
to attract students and explains better performance of government schools in Alberta and several other provinces that use the same approach. In the Province of Ontario, higher education financing assigns weights to enrollments in different programs, with medical and engineering education receiving higher weights than the humanities.

In conclusion, while output-based (performance-oriented) grants are best suited to grantor's objectives and are simpler to administer than traditional input-based conditional transfers, they are rarely practiced. The reasons have to do with the incentives faced by politicians and bureaucrats. Such grants empower clients while weakening the sphere for opportunism and pork barrel politics. The incentives they create strengthen the accountability of political and bureaucratic elites to citizens and weaken their ability to peddle influence and build bureaucratic empires. Their focus on value for money exposes corruption, inefficiency, and waste. Not surprisingly, this type of grant is blocked by potential losers.

\section{Compensating for Benefit Spillovers}

Compensating for benefit spillovers is the traditional argument for providing matching conditional grants. Regional and local governments will not face the proper incentives to provide the correct levels of services that yield spillover benefits to residents of other jurisdictions. A system of open-ended matching grants based on expenditures giving rise to spillovers will provide the incentive to increase expenditures. Because the extent of the spillover is usually difficult to measure, the matching rate will be somewhat arbitrary.

Although benefit-cost spillover is a serious factor in a number of countries, such transfers have not been implemented in developing countries other than South Africa. South Africa provides a closed-ended matching grant to teaching hospitals based on an estimate of benefit spillovers associated with enrollment of non-local students and use of hospital facilities by nonresidents.

\section{Influencing Local Priorities}

In a federation there is always some degree of conflict among priorities established by various levels of government. One way to induce 
lower-level governments to follow priorities established by the higher-level government is for the higher-level government to use its spending power by providing matching transfers. The higher-level government can provide open-ended matching transfers with a matching rate that varies inversely with the recipient's fiscal capacity. Use of ad hoc grants or open-ended matching transfers is inadvisable. Ad hoc grants are unlikely to result in behavioral responses that are consistent with the grantor's objectives. Open-ended grants may create budgetary difficulties for the grantor.

India, Malaysia, and Pakistan have conditional closed-ended matching programs. Pakistan got into serious difficulty in the late 1990s by offering open-ended matching transfers for provincial tax effort. The central government had to abandon this program midstream, after it proved unable to meet its obligations under the program.

\section{Dealing with Infrastructure Deficiencies and Creating Macroeconomic Stability in Depressed Regions}

Fiscal transfers can be used to serve central government objectives in regional stabilization. Capital grants are appropriate for this purpose, provided funds for future upkeep of facilities are available. Capital grants are also justified to deal with infrastructure deficiencies in poorer jurisdictions in order to strengthen the common economic union.

Capital grants are typically determined on project by project basis. Indonesia took a planning view of such grants in setting a national minimum standard of access to primary school (within walking distance of the community served) for the nation as a whole. The central government provided for school construction, while local governments provided land for the schools.

South Africa has experimented with a formula-based capital grant to deal with infrastructure deficiencies. The Municipal Infrastructure Grant formula includes a vertical and horizontal division. The vertical division allocates resources to sectors or other priority areas; the horizontal division is determined based on a formula that takes account of poverty, backlogs, and municipal powers and functions. The formula includes five components:

- Basic residential infrastructure, including new infrastructure and rehabilitation of existing infrastructure (75 percent weight); 
Proportional allocations are made for water supply and sanitation, electricity, roads, and "other" (street lighting and solid waste removal);

- Public municipal service infrastructure, including construction of new infrastructure and rehabilitation of existing infrastructure (15 percent weight);

- Social institutions and microenterprises infrastructure (5 percent weight);

- Nodal municipalities (5 percent weight);

- Final adjustment: A negative (downward adjustment) or positive (topup) allocation related to past performance of each municipality relative to grant conditions.

Experience with capital grants shows that they often create facilities that are not maintained by subnational governments, which either remain unconvinced of their utility or lack the means to provide regular upkeep.

Capital grants are pervasive in developing countries and transition economies. Most countries have complex processes for initiating and approving submissions for financing capital projects. These processes are highly susceptible to lobbying, political pressure, and grantsmanship, and they favor projects that give the central government greater visibility. Projects typically lack citizen and stakeholder participation, and they often fail due to lack of local ownership, interest, and oversight. In view of these difficulties, it may be best to limit the use of capital grants by requiring matching funds from recipients (varying inversely with the fiscal capacity of the recipient unit) and by encouraging private sector participation by providing political and policy risk guarantees. To facilitate private sector participation, public managers must exercise due diligence to ensure that the private sector does not take the public sector for a free ride or walk away from the project midstream.

\section{Special Issues in Transfers from State/Province to Local Governments}

General-purpose transfers to local governments require special considerations, as local governments vary in population, size, area served, 
and type of services offered. In view of this, it is advisable to classify local governments by population size, municipality type, and urban/rural character, creating separate formulas for each class of municipalities. The higher-level government could adopt a representative tax system-based fiscal capacity equalization system and set minimum standards grants for each class and type of municipality. Where the application of a representative tax system is not feasible due to lack of significant tax decentralization or poor local tax administration, a more pragmatic but less scientific approach to general-purpose grants could be used. Some useful components in these grant formulas are an equal per municipality component, an equal per capita component, a service area component, and a fiscal capacity component. Grant funds should vary directly with the service area and inversely with fiscal capacity (see Shah 1994b on examples of state-local transfers from Australia, Brazil, and Canada). South Africa has applied a variant of this approach in central-local transfers (Box 1.3).

Having a formal open, contestable, and deliberative process for municipal incorporation, amalgamation, and annexation should be a prerequisite for introducing an equal per municipality component in grant finance. The lack of such a process can create a perverse incentive for the break-up of existing jurisdictions to qualify for additional assistance, as demonstrated by the experience in Brazil (Shah 1991).

\section{Box 1.3 South Africa's Equitable Share Formula for Central- Local Fiscal Transfers}

South Africa uses an equitable share formula to provide transfers from the central government to local governments. The size of the grant is determined as follows:

Grant $=(B S+D+I-R) \pm C$,

where $B S$ is the basic services component, $D$ is the development component, $I$ is the institutional support component, $R$ is the revenueraising capacity correction, and $\mathrm{C}$ is a correction and stabilization factor.

\section{Basic Services Component}

The purpose of the basic services component is to enable municipalities to provide basic services (water, sanitation, electricity, refuse removal, 
and other basic services), including free basic services to households earning less than R800 (about US\$111) a month. (As of April 1, 2006, environmental health care services have been included as a basic service.) Since by its nature environmental health is delivered to everyone in a municipality, this subcomponent is calculated on all households, not only poor ones. For each subsidized basic service, there are two levels of support: a full subsidy for households that actually receive services from the municipality and a partial subsidy for unserviced households, currently set at one-third of the cost of the subsidy to serviced households. This component is calculated as follows:

$$
\begin{gathered}
\text { BS }=\text { [water subsidy } 1 * \text { poor with water }+ \text { water subsidy } 2 * \text { poor } \\
\text { without water] }+[\text { sanitation subsidy } 1 * \text { poor with sanitation }+ \\
\text { sanitation subsidy } 2 * \text { poor without sanitation] }+[\text { refuse subsidy } 1 * \\
\text { poor with refuse }+ \text { refuse subsidy } 2 * \text { poor without refuse] }+ \text { [electricity } \\
\text { subsidy } 1 * \text { poor with electricity }+ \text { electricity subsidy } 2 * \text { poor without } \\
\text { electricity] }+[\text { [environmental healthcare subsidy } * \text { total number of } \\
\text { households]. }
\end{gathered}
$$

\section{Institutional Support Component}

The institutional support component is particularly important for poor municipalities, which are often unable to raise sufficient revenue to fund the basic costs of administration and governance. Such funding gaps make it impossible for poor municipalities to provide basic services to all residents, clients, and businesses. This component supplements the funding of a municipality for administrative and governance costs. It does not fully fund all administration and governance costs of a municipality, which remain the primary responsibility of each municipality.

The institutional component includes two elements: administrative capacity and local electoral accountability. The grant is determined as follows:

$I=$ base allocation $+[$ admin support $*$ population $]+[$ council support $*$ number of seats]

where the values used in the formula are $I=\mathrm{R} 350,000+[\mathrm{R} 1 *$ population $]+[\mathrm{R} 36,000 *$ councillors $]$

The "base allocation" is the amount that goes to every municipal structure (except for a district management area). The second term of this formula recognizes that costs rise with population. The third term is a contribution 
to the cost of maintaining councillors for the legislative and oversight role. The number of "seats" that will be recognized for purposes of the formula is determined by the minister for provincial and local government.

\section{The Development Component}

The development component was set at zero when the current formula was introduced on April 1, 2005, pending an investigation of how best to capture the factor in the formula.

\section{The Revenue-Raising Capacity Correction}

The revenue-raising capacity correction raises additional resources to fund the cost of basic services and administrative infrastructure. The basic approach is to use the relationship between demonstrated revenue-raising capacity by municipalities that report information and objective municipal information from Statistics South Africa to proxy revenueraising capacity for all municipalities. The revenue that should be available to a municipality is then "corrected" by imposing a "tax" rate of 5 percent. In the case of the Regional Service Councils levy replacement grant, the correction is based on the actual grant to each municipality.

Source: South Africa (2006).

\section{Institutional Arrangements for Fiscal Relations}

Who should be responsible for designing the system of federalstate-local fiscal relations? There are various alternatives (see Shah, 2005 a for an evaluation framework and comparative reflections on alternate institutional arrangements). The first and most commonly used practice is for the federal/central government to decide on it alone. The most obvious one is to make the federal government solely responsible, on the grounds that it is responsible for the national objectives that are to be delivered through the fiscal arrangements. In many countries, this is the norm and one or more central government agencies assume exclusive responsibility for the design and allocation of fiscal transfers. A potential problem with this approach is the natural tendency of the federal government to be overly involved with state decisionmaking and not to allow the full benefits of decentralization to occur. This biases the system toward a centralized outcome, despite the fact that the grants are intended to facilitate decentralized decisionmaking. To some extent, this problem 
can be overcome by imposing constitutional restrictions on the ability of the federal government to override state and local decisions. In China, central government agencies assume sole responsibility without having any legislative checks (Shah and Shen, 2006). In India the federal government is solely responsible for Planning Commission transfers and centrally sponsored schemes. These transfers have strong input conditionality with potential to undermine state and local autonomy. The 1988 Brazilian constitution provides strong safeguards against federal intrusion by enshrining the transfers' formula factors in the constitution. These safeguards represent an extreme step, as they undermine the flexibility of fiscal arrangements to respond to changing economic circumstances.

Alternatively, a separate body could be involved in the design and ongoing reform and enforcement of fiscal arrangements. This could be an impartial body or a body made up of both federal and state representatives. It could have true decision making authority or be purely advisory. Whatever body is responsible, to be effective, it needs to be able to coordinate decisionmaking by the two levels of government. Three commonly practiced options are: (a) and idependent grants commission; (b) intergovernmental forum; and (c) intergovernmental-cum-civilsociety forum.

Some countries set up a quasi-independent body, such as a grants commission, to design and reform the fiscal system. Such commissions can have a permanent presence, as in Australia or South Africa, or they can be brought into existence periodically to make recommendations for the next five years, as in India. India has also instituted independent grants commissions at the state level as advisory bodies for state-local fiscal transfers. These commissions have proven ineffective in some countries, largely because many of their recommendations have been ignored by the government and not implemented, as in South Africa. In other cases the government may have accepted and implemented the commission's recommendations but been ineffective in reforming the system due to self-imposed constraints, as in India. In some cases these commissions become too rigorous and academic in their approaches, contributing to the creation of an overly complex system of intergovernmental transfers. This has been the case with the Commonwealth Grants Commission in Australia.

A few countries use intergovernmental forums or executive federalism or federal-provincial committees to negotiate the terms of the 
system, as Canada and Germany do. In Germany this system is enhanced by having state governments represented in the Bundesrat, the upper house of the parliament. This system allows for explicit political input from the jurisdictions involved and attempts to develop a common consensus. Typically such forums opt for simplicity in design to make the system transparent and politically acceptable.

Finally, a variant of the above is to use an intergovernmental cum legislative cum civil society committee with equal representation from all constituent units, chaired by the federal government to negotiate changes in existing federal-provincial fiscal arrangements. The Finance Commission in Pakistan is an example of this model, which is constituted periodically to determine allocations for the next five years.. Pakistan also follows the same approach by having province level finance commissions for designing and allocating provincial-local fiscal transfers. This approach has the advantage that all stakeholders - donors, recipients, civil society, and experts - are represented on the commission. Such an approach keeps the system simple and transparent. An important disadvantage of this approach is that due to the unanimity rule, such bodies may be permanently deadlocked, as has recently been witnessed at the federal level in Pakistan.

\section{Lessons from International Practices}

Review of international practices yields a set of practices to avoid and a set of practices to emulate. A number of important lessons also emerge (Table 1.7). 
Table 1.7

Principles and Better Practices in Grant Design

\begin{tabular}{|c|c|c|c|}
\hline Grant objective & Grant design & $\begin{array}{l}\text { Examples of better } \\
\text { practices }\end{array}$ & $\begin{array}{c}\text { Examples of } \\
\text { practices to avoid }\end{array}$ \\
\hline $\begin{array}{l}\text { Bridge fiscal } \\
\text { gap }\end{array}$ & $\begin{array}{l}\text { Reassignment of } \\
\text { responsibilities, tax } \\
\text { aba tem ent, tax-base } \\
\text { sharing }\end{array}$ & $\begin{array}{l}\text { Tax abatement and } \\
\text { tax-base sharing } \\
\text { (Canada) }\end{array}$ & $\begin{array}{l}\text { Deficit grants, wage } \\
\text { grants (China), tax by } \\
\text { tax sharing (China, } \\
\text { India) }\end{array}$ \\
\hline $\begin{array}{l}\text { Reduce regional } \\
\text { fiscal disparities }\end{array}$ & $\begin{array}{l}\text { General non matching } \\
\text { fiscal capacity } \\
\text { equalization transfers }\end{array}$ & $\begin{array}{l}\text { Fiscal equalization } \\
\text { with explicit standard } \\
\text { that determin es total } \\
\text { pool a s wellas } \\
\text { allocation (Canada, } \\
\text { Denmark, and } \\
\text { Germany) }\end{array}$ & $\begin{array}{l}\text { Gener al revenue } \\
\text { sharing with multiple } \\
\text { factors (Brazil and } \\
\text { India); fiscal } \\
\text { equalization with a } \\
\text { fixed pool (Australia, } \\
\text { China) }\end{array}$ \\
\hline $\begin{array}{l}\text { Compensate for } \\
\text { benefit } \\
\text { spillovers }\end{array}$ & $\begin{array}{l}\text { Open -ended matching } \\
\text { transfers with m atching } \\
\text { rate consistent with spill- } \\
\text { out of benefits }\end{array}$ & $\begin{array}{l}\text { Grant for teaching } \\
\text { hospitals (South } \\
\text { Africa) }\end{array}$ & $\begin{array}{l}\text { Closed-ended } \\
\text { matching grants }\end{array}$ \\
\hline \multirow[t]{2}{*}{$\begin{array}{l}\text { Set national } \\
\text { minimum } \\
\text { standards }\end{array}$} & $\begin{array}{l}\text { Condition al non matching } \\
\text { output -base d bloc } \\
\text { transfers with conditions } \\
\text { on standards of service } \\
\text { and access }\end{array}$ & $\begin{array}{l}\text { Road maintenance and } \\
\text { primary education } \\
\text { grants (Indonesia } \\
\text { before 2000) } \\
\text { Education transfers } \\
\text { (Brazil, Chile, } \\
\text { Colombia) } \\
\text { Health transfers } \\
\text { (Brazil, Canada ) }\end{array}$ & $\begin{array}{l}\text { Condition al transfers } \\
\text { with conditions on } \\
\text { spending alone (most } \\
\text { countries), pork } \\
\text { barrel transfers (USA } \\
\text { e.g. Year } 2006 \\
\text { US\$200 million } \\
\text { federal grant for } \\
\text { 'Bridg e to Nowhere' } \\
\text { in Alaska), } \\
\text { ad hoc grants }\end{array}$ \\
\hline & $\begin{array}{l}\text { Conditional capital grants } \\
\text { with matching rate that } \\
\text { varies invers ely with lo cal } \\
\text { fiscal capacity. }\end{array}$ & $\begin{array}{l}\text { Capital grant for } \\
\text { school construction } \\
\text { (Indonesia before } \\
\text { 2000), highway } \\
\text { construction matching } \\
\text { grants to states (United } \\
\text { States) }\end{array}$ & $\begin{array}{l}\text { Capital grants with } \\
\text { no matching and no } \\
\text { future upkeep } \\
\text { require ments }\end{array}$ \\
\hline $\begin{array}{l}\text { Influence local } \\
\text { priorities in } \\
\text { areas of high } \\
\text { national but low } \\
\text { local priority } \\
\end{array}$ & $\begin{array}{l}\text { Open-ended matching } \\
\text { transfers (preferably with } \\
\text { matching rate varying } \\
\text { inversely with fiscal } \\
\text { capacity) }\end{array}$ & $\begin{array}{l}\text { Matching transfers for } \\
\text { social assistance } \\
\text { (Canada before 2004) }\end{array}$ & Ad hoc grants \\
\hline $\begin{array}{l}\text { Provide } \\
\text { stabilization and } \\
\text { overcome } \\
\text { infrastructure } \\
\text { deficiencies }\end{array}$ & $\begin{array}{l}\text { Capital grants, provided } \\
\text { maintenance possible. }\end{array}$ & $\begin{array}{l}\text { Capital grants with } \\
\text { matching rates th at } \\
\text { vary inversely with } \\
\text { local fiscal capacity }\end{array}$ & $\begin{array}{l}\text { Stabilization grants } \\
\text { with no future upkeep } \\
\text { requirements }\end{array}$ \\
\hline
\end{tabular}

Source: Author. 


\section{Negative Lessons: Types of Transfers to Avoid}

Policymakers should avoid designing the following types of intergovernmental grants:

1. Grants with vaguely specified objectives;

2. General revenue-sharing programs with multiple factors that work at cross purposes, and undermine accountability and do not advance fiscal efficiency or fiscal equity objectives. Tax decentralization or taxbase sharing offer better alternatives to a general revenue-sharing program, as they enhance accountability while preserving subnational autonomy;

3. Grants to finance subnational deficits, which create incentives for running higher deficits in future;

4. Unconditional grants that include incentives for fiscal effort. Improving service delivery while lowering tax costs should be public sector objectives;

5. Input- (or process-) based or ad hoc conditional grant programs, which undermine local autonomy, flexibility, fiscal efficiency, and fiscal equity objectives;

6. Capital grants without assurance of funds for future upkeep, which have the potential to create white elephants;

7. Negotiated or discretionary grants in a federal system, which may create dissention and disunity;

8. One size fits all grants to local governments, which create huge inequities;

9. Grants that involve abrupt changes in the total pool and its allocation.

\section{Positive Lessons: Principles to Adopt}

Policymakers should strive to respect the following principles in designing and implementing intergovernmental transfers:

1. Keep it simple. In the design of fiscal transfers, rough justice may be better than full justice, if it achieves wider acceptability and sustainability;

2. Focus on a single objective in a grant program and make the design consistent with that objective. Setting multiple objectives in a single grant program runs the risk of failing to achieve any of them; 
3. Introduce ceilings linked with macro indicators and floors, to ensure stability and predictability in grant funds;

4. Introduce sunset clauses. It is desirable to have the grant program reviewed periodically - say, every five years - and renewed (if appropriate). In the intervening years, no changes to the program should be made, in order to provide certainty in budgetary programming for all governments;

5. Equalize per capita fiscal capacity to a specified standard in order to achieve fiscal equalization. Such a standard would determine the total pool and allocations among recipient units. Calculations required for fiscal capacity equalization using a representative tax system for major tax bases are doable for most countries. In contrast, expenditure need equalization requires difficult and complex analysis, inviting much controversy and debate; as desirable as it is, it may not therefore be worth doing. In view of this practical difficulty, it would be best to deal with fiscal need equalization through output-based sectoral grants that also enhance results-based accountability. A national consensus on the standard of equalization is critically important for the sustainability of any equalization program. The equalization program must not be looked at in isolation from the broader fiscal system, especially conditional transfers. The equalization program must have a sunset clause and provision for formal review and renewal. For local fiscal equalization, one size does not fit all;

6. In specific-purpose grant programs, impose conditionality on outputs or standards of access and quality of services rather than on inputs and processes. This allows grantors to achieve their objectives without undermining local choices on how best to deliver such services. Most countries need to establish national minimum standards of basic services across the nation in order to strengthen the internal common market and economic union;

7. Recognize population size class, area served, and the urban/rural nature of services in making grants to local governments. Establish separate formula allocations for each type of municipal or local government;

8. Establish hold harmless or grandfathering provisions that ensure that all recipient governments receive at least what they received as general-purpose transfers in the pre-reform period. Over time, as 
the economy grows, such a provision would not delay the phase-in of the full package of reforms;

9. Make sure that all stakeholders are heard and that an appropriate political compact on equalization principles and the standard of equalization is struck. Politics must be internalized in these institutional arrangements. Arms-length institutions, such as independent grant commissions, are not helpful, as they do not allow for political input and therefore tend to opt for complex and nontransparent solutions.

Moving from a public sector governance culture of dividing the spoils to an environment that enables responsive, responsible, equitable and accountable governance is critical. Doing so requires exploring all feasible tax decentralization options, instituting output-based operating and capital fiscal transfers, establishing a formal fiscal equalization program with an explicit standard of equalization, and ensuring responsible access to borrowing.

\section{REFERENCES}

Aubut, Julie, and François Vaillancourt. (2001). "Using GDP in Equalization Calculations: Are There Meaningful Measurement Issues?" Working Paper, Institute of Intergovernmental Relations, Queen's University, Kingston, Ontario, Canada.

Barati, Izabella, and Akos Szalai, (2000). "Fiscal Decentralization in Hungary." Centre for Public Affairs Studies, Budapest University of Economic Sciences, Budapest, Hungary.

Boadway, Robin 2002a. "Revisiting Equalization Again: Representative Tax System vs. Macro Approaches." Working Paper, Institute of Intergovernmental Relations, Queen's University, Kingston, Ontario, Canada

Boadway, Robin (2002b). "The Vertical Fiscal Gap: Conceptions and Misconceptions. Paper." Paper presented at the conference "Canadian Fiscal Arrangements: What Works, What Might Work Better,” Winnipeg, Manitoba, May 16-17.

Boadway, Robin (2004). "The Theory and Practice of Equalization." CESifo Economic Studies 50 (1): 211-54 
Boadway, Robin, and Anwar Shah. Forthcoming. Fiscal Federalism: Principles and Practices. New York: Cambridge University Press.

Boadway, Robin and Anwar Shah, eds., (2007). Intergovernmental Fiscal Transfers: Principles and the Practice. Washington, DC: World Bank

Canada, Government of. (2006). "Achieving a National Purpose: Putting Equalization Back on Track". Expert Panel Report on Equalization and Territorial Formula Financing, Department of Finance. Ottawa: Government of Canada

Filimon, R; T.Romer; and H. Rosenthal. (1982). "Asymmetric Information and Agenda Control: The Bases of Monopoly Power and Public Spending”. Journal of Public Economics, 17:51-70.

Gamkhar, Shama and Anwar Shah. (2006). "The Impact of Intergovernmental Fiscal Transfers: A Synthesis of the Conceptual and Empirical Literature". In Intergovernmental Fiscal Transfers: Principles and Practice, edited by Robin Boadway and Anwar Shah, chapter 8. Washington, DC: World Bank.

Gomez-Lobo, Andres, (2002). "Making Water Affordable". In Brooke, Penelope, and Suzanne Smith, editors, Contracting for Public Services. 23-29, Washington, DC: World Bank.

Gonzalez, Pablo. (2005). "The Financing of Education in Chile". Fund for the Study of Public Policies, University of Chile, Santiago, Chile.

Gordon, Nora, and Emiliana Vegas. (2004). "Education Finance Equalization, Spending, Teacher Quality and Student Outcomes: The Case of Brazil's FUNDEF." Education Sector, Human Development Department, Latin America and the Caribbean Region, World Bank, Washington, DC.

Gramlich, Edward. (1977). "Intergovernmental Grants: A Review of the Empirical Literature." In The Political Economy of Fiscal Federalism, ed. Wallace Oates, 219-239. Lexington, MA: Heath.

Huther, Jeff, Sandra Roberts, and Anwar Shah. 1997. Public Expenditure Reform under Adjustment Lending: Lessons from World Bank Experiences. Washington, DC: World Bank..

McMillan, Melville, Anwar Shah, and David Gillen. (1980). "The Impact of Provincial-Municipal Transportation Subsidies." Alberta Transportation, Edmonton, Alberta, Canada. 
Oates, W.E. (2005). "Towards a Second Generation Theory of Fiscal Federalism." International Tax and Public Finance 12 (4): 349-73.

Oates, Wallace, E. (1999). “ An Essay on Fiscal Federalism'. Journal of Economic Literature 37 (September), 1120-49.

Rosen, Harvey S. (2005). Public Finance. Seventh Edition. Boston: McGraw-Hill/Irwin.

Shah, Anwar. (1985). "Provincial Transportation Grants to Alberta Cities: Structure, Evaluation, and a Proposal for an Alternate Design." In Quantity and Quality in Economic Research, ed. Roy Chamberlain Brown, vol. 1, 59-108. New York: University Press of America.

Shah, Anwar. (1988a). "Capitalization and the Theory of Local Public Finance: An Interpretive Essay". Journal of Economic Surveys 2(3):209-243.

Shah, Anwar. (1988b). "An Empirical Analysis of Public Transit Subsidies in Canada." In Quantity and Quality in Economic Research, ed. Roy Chamberlain Brown, vol. II, 15-26. New York: University Press of America.

Shah, Anwar. (1989). "A Linear Expenditure System Estimation of Local Response to Provincial Transportation Grants." Kentucky Journal of Economics and Business 2(3): 150-168.

Shah, Anwar. (1991). The New Fiscal Federalism in Brazil. Washington, DC.: World Bank

Shah, Anwar. (1994a). "A Fiscal Need Approach to Equalization Transfers in a Decentralized Federation." World Bank Policy Research Working Paper 1289, Washington, DC.

Shah, Anwar. (1994b). The Reform of Intergovernmental Fiscal Relations in Developing and Emerging Market Economies. Washington, DC: World Bank

Shah, Anwar. (1996). "A Fiscal Need Approach to Equalization”. Canadian Public Policy 22 (2): 99-115.

Shah, Anwar. (1998). "Indonesia and Pakistan: Fiscal DecentralizationAn Elusive Goal?" In Fiscal Decentralization in Developing Countries, ed. Richard Bird and François Vaillancourt, 115-51. Cambridge: Cambridge University Press. 
Shah, Anwar. (2004). "The Australian Horizontal Fiscal Equalization Program in the International Context". Presentation at the Heads of the Australian Treasuries (HOTS) Forum, Canberra, September 22, and the Commonwealth Grants Commission, Canberra, September 23.

Shah, Anwar. (2005a). "A Framework for Evaluating Alternate Institutional Arrangements for Fiscal Equalization Transfers". World Bank Policy Research Working Paper 3785, Washington, DC.

Shah, Anwar. (2005b). "On Getting the Giant to Kneel: Approaches to a Change in the Bureaucratic Culture". In Fiscal Management, ed. Anwar Shah, 211-227. Washington, DC: World Ban

Shah, Anwar. and Chunli Shen. (2006). "Fine Tuning the Intergovernmental Transfer System To Achieve A Harmonious Society and A Level Playing Field for Regional Development in China". Paper presented at the International Seminar in Public Finance, State Guest House, Beijing, China, June 26-28, 2006.

Shankar, Raja and Anwar Shah. (2003). "Bridging the Economic Divide Within Countries: A Scorecard on the Performance of Regional Policies in Reducing Regional Income Disparities". World Development 31(8):1421-1441.

South Africa, Government of. (2006). "Budget 2006". National Budget Review. Pretoria: Government Printing Service.

Vaillancourt, François. (1998). Financing Formulas for Public PrimarySecondary Educations in the United States: Presentation and Evaluation. World Bank, Economic Development Institute, Washington, DC.

World Bank. (2001). "Brazil: Issues in Brazilian Fiscal Federalism". Report 22523-BR, Brazil Country Management Unit, Washington, DC.

World Bank. (2006). Capitation Financing Options in the Health Sector: International Experience. Uzbekistan Programmatic Public Expenditure Review. Europe and Central Asia Region, Washington, DC. 


\section{REVISTA DE ECONOMÍA Y ESTADÍSTICA \\ Instituto de Economía y Finanzas \\ Facultad de Ciencias Económicas \\ Universidad Nacional de Córdoba}

\section{INSTRUCCIONES PARA LOS AUTORES}

\section{Normas Generales}

Se reciben para su posible publicación en la Revista de Economía y Estadística trabajos en idioma español o inglés, inéditos y que no estén siendo sometidos simultáneamente para su publicación en otros medios. Todo trabajo recibido estará sujeto a la aprobación de un Comité de Árbitros, especialistas de reconocido prestigio. El procedimiento que se utiliza es el doble ciego (autores y árbitros anónimos).

Los originales deberán presentarse en versión electrónica (en Word y Excel) y ser enviados a los editores de la Revista a la siguiente dirección electrónica: rev_eco_estad@eco.unc.edu.ar. Es responsabilidad del autor asegurarse que el archivo sea completamente legible en cualquier computadora personal (no solamente en aquella sobre la cual el artículo fue compuesto). No serán aceptados archivos ilegibles.

Los Editores no aceptan la responsabilidad por el daño o la pérdida de artículos presentados. Sobre la aceptación de un artículo, se pedirá al autor/es transferir los derechos de autor del artículo al editor. Esta transferencia asegurará la diseminación más amplia posible de información.

\section{TiPOS DE CONTRIBUCIONES}

Artículos 
Artículos breves

Crítica bibliográfica

'Observatorio de Política'

\section{Normas Editoriales}

El autor enviará el trabajo de acuerdo con las siguientes normas editoriales:

Extensión: los artículos deberán estar escritos a doble espacio, con márgenes de 2,5 cm.; la extensión promedio será de veinticinco (25) páginas, numeradas consecutivamente (la página del título es la página 1) y en ningún caso podrán superarse las cuarenta (40) páginas.

La primer página del artículo deberá contener la siguiente información:

Título: debe ser corto, explicativo y contener la esencia del trabajo.

Autor (es): indicar los nombres y apellidos completos sin títulos profesionales, seguido de la dirección postal (institucional o particular según corresponda) y dirección de correo electrónico.

Resumen: los trabajos deberán ir acompañados por un resumen en español y en inglés. El resumen debe escribirse en un solo párrafo de no más de 100 palabras. Contendrá una descripción del problema, los objetivos, la metodología y las principales observaciones y conclusiones.

Palabras claves: se debe incluir la clasificación JEL (JOURNAL OF ECONOMIC LITERATURE CLASSIFICATION SYSTEM) disponible en Internet y hasta cinco palabras claves que definan el artículo.

Referencias: todas las referencias bibliográficas citadas en el texto deberán ser presentadas alfabéticamente, y estar escritas según las normas de la International Organization for Standardization. ISO 690 - documentos impresos y materiales especiales e ISO 690-2 Documentos electrónicos y sus partes. Se puede consultar en Internet ambos documentos. ISO 690; ISO 690-2.

Tablas (cuadros) y Figuras (gráficos): tanto las tablas como las figuras se numerarán con números arábigos y cada una llevará una leyenda y la fuente si fuera el caso. Si en una figura se incluyen fotografías, deberán presentarse en forma de copias en blanco y negro, brillantes y de muy buena calidad. Ejemplos 
Figura 1

Precios de las acciones y riesgo/país

Fuente: JPMorgan

Tabla 1

Cambios de tipo de tenencia de la vivienda

Fuente: encuesta movilidad espacial en Bogotá, Centro de Estudios sobre el Desarrollo Económico (CEDE), 1993.

Las tablas, referencias y leyendas para figuras deberán ser escritas en páginas separadas.

Fórmulas: deberán ser numeradas consecutivamente como (1), (2), etc. sobre el lado derecho de la página. Si la derivación de fórmulas ha sido abreviada, se recomienda presentar por separado, cuando sea pertinente, la derivación completa (que no será publicada).

Notas al pie de página: deberán ser en un mínimo y numeras consecutivamente en todas partes del texto con números en superíndice. Deberán ser escritas a doble espacio y no incluir fórmulas.

Nombre de organizaciones y/o instituciones: deberá indicarse la denominación completa, con su correspondiente sigla entre paréntesis, de toda organización o institución mencionada en el trabajo.

Anexo: con la base de datos, cuando corresponda, es conveniente el envío en un archivo adjunto, de los datos utilizados para las estimaciones y/o construcción de tablas y gráficos.

\section{INSTRUCTIONS FOR AUTHORS}

\section{GENERAL INFORMATION}

Papers submitted for publication in Revista de Economía y Estadística must be written in Spanish or English and should not simultaneously be submitted for publication in other journals. Received papers will be considered by a Board of Associate Editors, composed by well known and prestigious specialists. Articles will be subject to the double blind procedure (anonymous authors and referees).

Electronic versions of originals (word or excel) must be sent to the Editors 
to the following e-mail address: rev_eco_estad@eco.unc.edu.ar. It is the authors' responsibility to ensure that the file is completely legible in any personal computer (not only in the one in which the article was written). Not legible files will not be accepted.

The Editors will not take any responsibility for any damage or loss of submitted articles. On papers acceptance, authors will be asked to transfer their property rights to the Editors in order that the amplest dissemination of information can be guaranteed.

\section{TyPes OF CONTRIBUTIONS}

Articles

Short Articles

Bibliographical Reviews

Contributions to Policy Watch

\section{Manuscript Preparation}

Papers' length. Submitted articles should typically be less than 25 doublespaced pages with $2.5 \mathrm{~cm}$ margins on all sides, and should in no event exceed 40 pages. Pages should be consecutively numbered (the title page being number 1).

Title page. The title page will include:

The article title, which should be short, self explaining and bearing the paper's essence.

The authors' name and permanent affiliations, followed by their current postal address, e-mail address and telephone or fax number.

The title page will also include single paragraph abstracts, in Spanish and in English, of not more than 100 words each and a list of two to five keywords.

Footnotes. Footnotes will be kept at a minimum and numbered consecutively and designated by superscripts in the text. All footnotes should be typed double-spaced and they will not include formula.

References. All bibliographical references quoted in the text should follow the format prescribed by the International Organization for Standardization-ISO 690 (printed documents and special materials) and ISO 690-2 (electronic documents and their parts), available in internet for 
consultation. The list of references will be presented in alphabetic order.

Formula. They should be numbered consecutively throughout the text [e.g. (1), (2), etc] on the right of the page. It is recommended, in case of abbreviated formula display, to separately submit their complete derivation (which will be not published).

Tables and Figures. Tables as well as figures should be identified with Arabic numbers and will have a legend and the source (whenever it applies). Figures carrying photographs will be presented in brilliant, good quality white and black copies. Tables, references and figure legends should be written in separate pages.

Organizations and Institutions. Organizations and Institutions quoted or mentioned in the paper will be indicated with their complete denomination and the corresponding initials between brackets.

Annex. Authors are advised to send, enclosed to the paper, the file with the database used for estimations and the construction of tables and graphics. 